\title{
Third cumulative index for Koedoe: volumes 35/2-44/1
}

\section{Compiled by J.C. Rautenbach}

Previous indexes can be found in Koedoe 25 (1982) and Koedoe 35/1 (1992).

J.C. Rautenbach, South African National Parks, P.O. Box 787, Pretoria, 0001 Republic of South Africa.

\section{Index to Koedoe: volumes $35 / 2-44 / 1$}

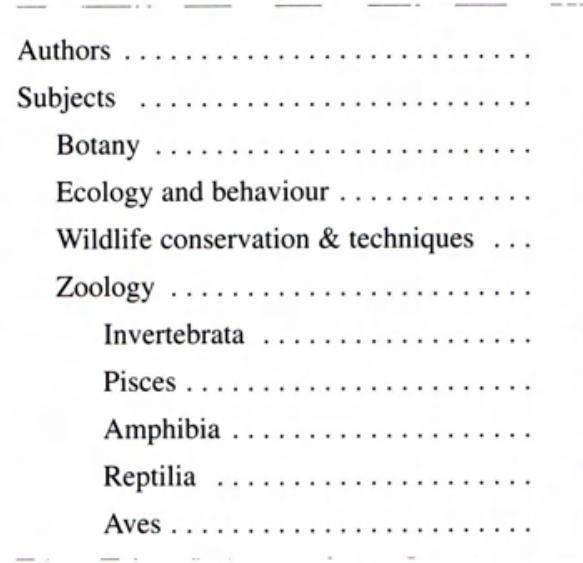

85

98

98

100

100

102

102

103

103

103

104
Mammalia

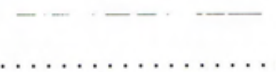

104

Archaeology and History . . . . . . . . . 105

Bibliography ................ 106

Climate .................... 106

Geology and Pedology $\ldots \ldots \ldots \ldots . \ldots . . \ldots 6$

Environmental impact on rivers \& water quality 106

Check list ... . . . . . . . . . . . 107

Issues in conservation $\ldots \ldots \ldots \ldots \ldots . . \ldots 107$

Maps $\ldots \ldots \ldots \ldots \ldots \ldots \ldots \ldots . \ldots \ldots$

Social Science . . . . . . . . . . . . . 108

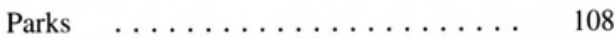

\section{Authors}

ACKERMAN, D.J., A.J. REINECKE and H.J. ELS. 1996a. A scanning electron microscopic study of impala (Aepyceros melampus) sperm from the Kruger National Park. Koedoe 39(2): 91-104.

ACKERMAN, D.J., A.J. REINECKE and H.J. ELS. 1996b. Transmission electron microscopic study of impala (Aepyceros melampus) sperm from the Kruger National Park. Koedoe 39(2): 105-120.

ACKERMAN, D.J., A.J. REINECKE and H.J. ELS. 1997a. Transmission electron microscopic observations of flagellum abnormalities in impala (Aepyceros melampus) sperm from the Kruger National Park. Koedoe 40(1): 1-13.

ACKERMAN, D.J., A.J. REINECKE and H.J. ELS. 1997b. Transmission electron microscopic observations of acrosome and head abnormalities in impala (Aepyceros melampus) sperm from the Kruger National Park. Koedoe 40(1):15-30.

ANDERSON, M.D. and J.H. KOEN. 1993. Body measurements of mountain reedbuck Redunca fulvorufula fulvorufula from Rolfontein Nature Reserve, South Africa. Koedoe 36(1): 99-101.

\section{ARCHER , FIONA}

see WEBLEY, LITA, FIONA ARCHER and J. BRINK. 1993.

AVENANT, N.L. 1997. Mammals recorded in the QwaQwa National Park (1994-1995). Koedoe 40(1): 31-40.

AVENANT-OLDEWAGE, ANNEMARIÉ. 1994. A new species of Argulus from Lake Kosi Bay, South Africa and distribution records of the genus. Koedoe 37(2): 89-96.

AVENANT-OLDEWAGE, A.see

MARX, H.M. and A. AVENANT-OLDEWAGE. 1998.

AVENANT-OLDEWAGE, ANNEMARIé and ELMINE KNIGHT. 1994. A diagnostic species compendium of the genus Chonopeltis Thiele, 1900 (Crustacea: Branchiura) with notes on its geographical distribution. Koedoe 37(1): 41-56.

AVENANT-OLDEWAGE, ANNEMARIÉ and HAZEL MARX. 2000. Manganese, nickel and strontium bioaccumulation in the tissues of the African sharptooth catfish, Clarias gariepinus 
from the Olifants River, Kruger National Park. Koedoe 43(2): 17-33.

BANCROFT, C.M., H. BEZUIDENHOUT and J.G. NEL. 1998. Use of veld condition assessment to set objectives and targets for an ISO 14001 environmental management system for Vaalbos National Park. Koedoe 41(2): 1-12.

BEGG, K.S. see

KEMP, A.C., K.S. BEGG, G.A. BENN and P. CHADWICK. 1997.

BENN, G.A. see

KEMP, A.C., K.S. BEGG, G.A. BENN and P. CHADWICK. 1997.

BEZUIDENHOUT, H. 1994. An ecological study of the major vegetation communities of the Vaalbos National Park, Northern Cape. 1. The ThanDroogeveld section. Koedoe 37(2): 19-44.

BEZUIDENHOUT, H. 1995. An ecological study of the major vegetation communities of the Vaalbos National Park, Norhtern Cape. 2. The GraspanHolpan section. Koedoe 38(2): 65-83.

BEZUIDENHOUT, $\mathrm{H}$. 1996. The major vegetation communities of the Augrabies Falls National Park, Northern Cape. 1. The southern section. Koedoe 39(2): 7-24.

BEZUIDENHOUT, $\mathrm{H}$. and CHRISTINE L. JARDINE. 2001. A reconnaissance botanical survey of the Lower Orange River (Blouputs to Onseepkans) in the Northern Cape, South Africa. Koedoe 44(1): 1-8.

BEZUIDENHOUT, H., G.J. BREDENKAMP and G.K. THERON. 1994. Phytosociological classes of the western Transvaal grassland, South Africa. Koedoe 37(1): 1-18.

BEZUIDENHOUT, H., H.C. BIGGS and G.J. BREDENKAMP. 1996. A process supported by the utility BBPC for analysing Braun-Blanquet data on a personal computer. Koedoe 39(1): 107-112.

BEZUIDENHOUT, $\mathrm{H}$. see

BANCROFT, C.M., H. BEZUIDENHOUT and J.G. NEL. 1998.

BEZUIDENHOUT, $\mathrm{H}$. see

BREDENKAMP, G.J. and H. BEZUIDENHOUT. 1995.

BEZUIDENHOUT, $\mathrm{H}$. see

BREDENKAMP, G.J., H. BEZUIDENHOUT, $\mathrm{H}$. JOUBERT and C. NAUDE. 1994.

BEZUIDENHOUT, H. see

BROWN, L.R. and H. BEZUIDENHOUT. 2000.

BEZUIDENHOUT, $\mathrm{H}$. see

DE KLERK, J., L.R. BROWN, H. BEZUIDENHOUT and G. CASTLEY. 2001.

BEZUIDENHOUT, $\mathrm{H}$. see

VAN ROOYEN, $\mathrm{N}$. and H. BEZUIDENHOUT. 1997.

BEZUIDENHOUT, $\mathrm{H}$. see

ZIETSMAN, P.C. and H. BEZUIDENHOUT. 1999.

BHIMA, R. and J. DU P. BOTHMA. 1997. Age structure of elephants in Liwonde National Park, Malawi. Koedoe 40(2): 1-8.
BHIMA, R. and C.O. DUDLEY. 1997. The influence of the Shire River on Liwonde National Park, Malawi, with special reference to elephant movements. Koedoe 40(2): 9-18.

BIGGS, H.C. and A.L.F. POTGIETER. 1999. Overview of the fire management policy of the Kruger National Park. Koedoe 42(1): 101-110.

BIGGS, H.C. see

BEZUIDENHOUT, H., H.C. BIGGS and G.J. BREDENKAMP. 1996.

BIGGS, H.C. see

ENSLIN, B.W., A.L.F. POTGIETER, H.C. BIGGS and R. BIGGS. 2000.

BIGGS, H.C. see

MEYER, V.W., L.E.O. BRAACK and H.C. BIGGS. 2000.

BIGGS, H. see

NOVELLIE, P., H. BIGGS, L. BRAACK, N. HANEKOM, M. KNIGHT, M. MACGREGOR, R. RANDALL, I. RUSSELL and F. VENTER. 1999.

BIGGS, H.C. see

SOLOMON, M., N. ZAMBATIS, H.C. BIGGS and N. MARÉ. 1999.

BIGGS, H.C. see TROLLOPE, W.S.W., L.A. TROLLOPE, H.C. BIGGS, D. PIENAAR and A.L.F. POTGIETER. 1998.

BIGGS, H.C. see VAN WILGEN, B.W., H.C. BIGGS and A.L.F. POTGIETER. 1998.

BIGGS, H.C. see

WHYTE, I.J., H.C. BIGGS, A. GAYLARD and L.E.O. BRAACK. 1999.

BIGGS, H.C. see ZAMBATIS, N and H.C. BIGGS. 1995.

BIGGS, R. see

ENSLIN, B.W., A.L.F. POTGIETER, H.C. BIGGS and R. BIGGS. 2000.

BINGHAM, M.G. see

CAULDWELL, A.E., U.ZIEGER, M.G. BINGHAM and G.J. BREDENKAMP. 1998.

BOTHA, ANNELIZE and J. HEYNS. 1992. Further records and descriptions of nematodes from rivers in the Kruger National Park (orders Enoplida, Chromadorida, Monhysterida, Mononchida and Araeolaimida). Koedoe 35(2): 11-25.

BOTHA, ANNELIZE and J. HEYNS. 1993a. New records of Tylenchida, Araeolaimida and Enoplida from the Kruger National Park, with an addendum to the check list of nematode species in the park. Koedoe 36(1): 61-65.

BOTHA, ANNELIZE and J. HEYNS. 1993b. Species of the genera Oxydirus, Dorylaimellus (Axodorylaimellus), Laimydorus and Rhabdolaimus from rivers in the Kruger National Park (Nematoda: Dorylaimida and Araeolaimida). Koedoe 36(1): 49-60.

BOTHMA, J. DU P. and E.A.N. LE RICHE. 1993. Disturbance bias when tracking Kalahari leop- 
ards Panthera pardus by spoor. Koedoe 36(2): 109-112.

BOTHMA J. du P. and E.A.N. LE RICHE. 1994. Range use by an adult male caracal in the southern Kalahari. Koedoe 37(2): 105-108.

BOTHMA J. du P., N. VAN ROOYEN and E.A.N. LE RICHE. 1997. Multivariate analysis of the hunting tactics of Kalahari leopards. Koedoe 40(1): 41-56.

BOTHMA, J. DU P., S. VAN HOVEN and E.A.N. LE RICHE. 1993. GPS-corrected and GIS-based remapping of the Kalahari Gemsbok National Park and the adjacent area in Botswana. Koedoe 36(2): 105-108.

BOTHMA, J. DU P. see BHIMA, R. and J. DU P. BOTHMA. 1997.

BOTHMA, J.DU P. see

ELS, H. and J. DU P. BOTHMA. 2000.

BOTHMA, J. DU P. see

PIENAAR, D. J., J. DU P. BOTHMA and G. K. THERON. 1993.

BOTHMA, J. DU P. see

THRASH, I., G.K. THERON and J. DU P. BOTHMA. 1993.

BRAACK, L.E.O. 1995. Seasonal activity of savanna termites during and after severe drought. Koedoe 38(1): 73-82.

BRAACK, L.E.O. see HORAK, I.G., V. DE VOS and L.E.O. BRAACK. 1995.

BRAACK, L.E.O. see MEYER, V.W., L.E.O. BRAACK and H.C. BIGGS. 2000.

BRAACK, L. see NOVELLIE, P., H. BIGGS, L. BRAACK, N. HANEKOM, M. KNIGHT, M. MACGREGOR, R. RANDALL, I. RUSSELL and F. VENTER. 1999.

BRAACK, L.E.O. see SPICKETT, A.M., I.G. HORAK, HELOISE HEYNE and L.E.O. BRAACK. 1995.

BRAACK, L.E.0. see WHYTE, I.J., H.C. BIGGS, A. GAYLARD and L.E.O. BRAACK. 1999.

BRADLEY, S. see

SCHOLES, R.J., N. GUREJA, M. GIANNECCHINNI, D. DOVIE, B. WILSON, N. DAVIDSON, K. PIGGOTT, C. MCLOUGHLIN, K. VAN DER VELDE, A FREEMAN, S. BRADLEY, R. SMART and S. NDALA. 2001.

BRANCH, W.R. and G.V. HAAGNER. 1992. New reptile records from three southern national parks. Koedoe 35(2): 59-60.

BREDENKAMP, G.J., H. BEZUIDENHOUT, $\mathrm{H}$. JOUBERT and C. NAUDE. 1994. The vegetation of the Boskop Dam Nature Reserve, Potchefstroom. Koedoe 37(1): 19-33.

BREDENKAMP, G.J. and H. BEZUIDENHOUT. 1995. A proposed procedure for the analysis of large phytosociological data sets in the classifica- tion of South African grasslands. Koedoe 38(1): 33-39.

BREDENKAMP, G.J. and M.S. DEUTSCHLÄNDER. 1994. The Themedo triandrae - Setarietum incrassatae, a new association from gabbro in the Manyeleti Game Reserve, Gazankulu, South Africa. Koedoe 37(2): 45-58.

BREDENKAMP, G.J. and M.S. DEUTSCHLÄNDER. 1995. New azonal syntaxa from the hills and river banks of the Manyeleti Game Reserve, Northern Transvaal Province, South Africa. Koedoe 38(1): 41-58.

BREDENKAMP, G.J. see BEZUIDENHOUT, H., H.C. BIGGS and G.J. BREDENKAMP. 1996.

BREDENKAMP, G.J. see BEZUIDENHOUT, H., G.J. BREDENKAMP and G.K. THERON. 1994.

BREDENKAMP, G.J. see BROWN, L.R., G.J. BREDENKAMP and N. VAN ROOYEN. 1995.

BREDENKAMP, G.J. see BROWN, L.R., G.J. BREDENKAMP and N. VAN ROOYEN. 1996

BREDENKAMP, G.J. see BROWN, L.R. and G.J. BREDENKAMP. 1994.

BREDENKAMP, G.J. see CAULDWELL, A.E., U.ZIEGER, M.G. BINGHAM and G.J. BREDENKAMP. 1998.

BREDENKAMP, G.J. see CILLIERS, S.S., E. VAN WYK and G.J BREDENKAMP. 1999.

BREDENKAMP, G.J. see DEUTSCHLÄNDER, M.S. and G.J. BREDENKAMP. 1999.

BREDENKAMP, G.J. see DU PLESSIS, W.P., G.J. BREDENKAMP and W.S.W. TROLLOPE. 1998a.

BREDENKAMP, G.J. see DU PLESSIS, W.P., G.J. BREDENKAMP and W.S.W. TROLLOPE. 1998b.

BREDENKAMP, G.J. see ECKHARDT, H.C., N. VAN ROOYEN and G.J. BREDENKAMP 1996.

BREDENKAMP, G.J. see ECKHARDT, H.C., N. VAN ROOYEN and G.J. BREDENKAMP. 1997.

BREDENKAMP, G.J. see MATTHEWS, W.S. G.J. BREDENKAMP and N. VAN ROOYEN. 1994.

BREDENKAMP, G.J. see SMIT, C.M., G.J. BREDENKAMP, N. VAN ROOYEN, A.E. VAN WYK and J.M. COMBRINCK. 1997.

BREEBAART, L. and M. DEUTSCHLÄNDER. 1997. The vegetation types and management units of Goedverwacht farm in the mixed bushveld of the Northern Province, South Africa. Koedoe 40(2): 19-35.

BREYTENBACH, G.J. see SONNEKUS, I.P. and G.J. BREYTENBACH. 2000 . 
BREYTENBACH, G.J. see SONNEKUS, I.P. and G.J. BREYTENBACH. 2001a.

BREYTENBACH, G.J. see SONNEKUS, I.P. and G.J. BREYTENBACH. $2001 \mathrm{~b}$.

BRINK, J. see WEBLEY, LITA, FIONA ARCHER and J. BRINK. 1993.

BRITS, J, M.W. VAN ROOYEN and N. VAN ROOYEN. 2000. Technique to study the impact of large herbivores on woody vegetation within piospheres. Koedoe 43(2): 47-56.

BROCKETT, B.H. see PARR, C.L. and B.H. BROCKETT. 1999.

BRONNER, G.N. 1992. Notes on the early postnatal development of a giant golden mole Chrysospalax trevelyani (Günther, 1875) born in captivity (Mammalia: Insectivora; Chrysochloridae). Koedoe 35(2): 57-58.

BRONNER, G.N. see

RAUTENBACH, I.L., G.N. BRONNER, and D.A. SCHLITTER. 1993.

BROWN, L.R. and H. BEZUIDENHOUT. 2000. The phytosociology of the De Rust section of the Mountain Zebra National Park, Eastern Cape. Koedoe 43(1): 1-18.

BROWN, L.R. and G.J. BREDENKAMP. 1994. The phytosociology of the southern section of Borakalalo Nature Reserve, South Africa. Koedoe 37(2): 59-72.

BROWN, L.R., G.J. BREDENKAMP and N. VAN ROOYEN. 1995. The phytosociology of the western section of Borakalalo Nature Reserve. Koedoe 38(2): 49-64.

BROWN, L.R., G.J. BREDENKAMP and N. VAN ROOYEN. 1996. The phytosociology of the northern section of the Borakalalo Nature Reserve. Koedoe 39(1): 9-24.

BROWN, M.A. see CHAPPELL, C.A. and M.A. BROWN. 1993.

BROWN, L.R. see

DE KLERK, J., L.R. BROWN, H. BEZUIDENHOUT and G. CASTLEY. 2001.

BROUWER, P.D. see WOOD, A.D., S.L. BROUWER, P.D. COWLEY and T.D. HARRISON. 2000.

BUERMANN, Y., H.H. DU PREEZ, G.J. STEYN, J.T. HARMSE and A. DEACON. 1995. Suspended silt concentrations in the lower Olifants River (Mpumalanga) and the impact of silt releases from the Phalaborwa Barrage on water quality and fish survival. Koedoe 38(2): 11-34.

BUXTON, C.D. see MANN, B.Q. and C.D. BUXTON. 1992.

CARINUS, T.V.Z. see HANEKOM, N., J.B. MANN-LANG, B.Q. MANN and T.V.Z. CARINUS. 1997.

CARRUTHERS, JANE. 1993. 'Police boys' and poachers: Africans, wildlife protection and national parks, the Transvaal 1902 to 1950 . Koedoe 36(2): 11-22.

CASEY, N.H. see WRENCH, J.M., H.H. MEISSNER, C.C. GRANT and N.H. CASEY. 1996.

CASTLEY, G. see

DE KLERK, J., L.R. BROWN, H. BEZUIDENHOUT and G. CASTLEY. 2001.

CAULDWELL, A.E., U.ZIEGER, M.G. BINGHAM and G.J. BREDENKAMP. 1998. Classification of the natural vegetation of Mtendere Game Ranch in the Chibombo District of the Central Province, Zambia. Koedoe 41(2): 13-26.

CHADWICK, P. see

KEMP, A.C., K.S. BEGG, G.A. BENN and P. CHADWICK. 1997.

CHAPPELL, C.A. and M.A. BROWN. 1993. The use of remote sensing in quantifying rates of soil erosion. Koedoe 36(1): 1-14.

CILLIERS, S.S., E. VAN WYK and G.J BREDENKAMP. 1999. Urban nature conservation: vegetation of natural areas in the Potchefstroom municipal area, North West Province, South Africa. Koedoe 42(1): 1-30.

COCKCROFT, V.G. see

KARCZMARSKI, L., V.G. COCKCROFT, A. MCLACHLAN and P.E.D. WINTER.

COMBRINCK, J.M. see

SMIT, C.M., G.J. BREDENKAMP, N. VAN ROOYEN, A.E. VAN WYK and J.M. COMBRINCK. 1997.

CORDES, I.G. and P. LE F.N. MOUTON. 1996. The conservation status of the Saldanha-Langebaan lizard fauna. Koedoe 39(1): 71-84.

COWLEY, P.D. see

WOOD, A.D., S.L. BROUWER, P.D. COWLEY and T.D. HARRISON. 2000.

DANNHAUSER, C.S. see

PRETORIUS, QUARTA, B.P. PRETORIUS and C.S. DANNHAUSER. 1996.

DAVIDSON, N. see

SCHOLES, R.J., N. GUREJA, M. GIANNECCHINNI, D. DOVIE, B. WILSON, N. DAVIDSON, K. PIGGOTT, C. MCLOUGHLIN, K. VAN DER VELDE, A FREEMAN, S. BRADLEY, R. SMART and S. NDALA. 2001.

DEACON, A. see

BUERMANN, Y., H.H. DU PREEZ, G.J. STEYN, J.T. HARMSE and A. DEACON. 1995.

DEACON, A. see

SEYMORE, T., H.H. DU PREEZ, J.H.J. VAN VUREN, A. DEACON and G. STRYDOM. 1994.

DE JAGER, MARIE see DIPPENAAR-SCHOEMAN, ANNA S., ASTRI LEROY, MARIE DE JAGER and ANNETTE VAN DEN BERG. 1999.

DE KLERK, J., L.R. BROWN, H. BEZUIDENHOUT and G. CASTLEY. 2001. The estimation of herbage yields under fire and grazing treat- 
ments in the Mountain Zebra National Park. Koedoe 44(1): 9-15.

DE KOCK, K.N. and C.T. WOLMARANS. 1998. A re-evaluation of the occurrence of freshwater molluscs in the Kruger National Park. Koedoe 41(1): 1-8

DERRY, J.F. see THRASH, I. and DERRY, J.F. 1999.

DE SWARDT, D.H. and D.J. VAN NIEKERK. 1996. An annotated check list of the birds of Qwaqwa National Park. Koedoe 39(1): 89-106.

DEUTSCHLÄNDER, M.S. and G.J. BREDENKAMP. 1999. Importance of vegetation analysis in the conservation management of the endangered butterfly Aloeides dentatis dentatis (Swierstra) (Lepidoptera, Lycaenidae). Koedoe 42(2): $1-12$

DEUTSCHLÄNDER, M.S. see BREDENKAMP, G.J. and M.S. DEUTSCHLÄNDER. 1994.

DEUTSCHLÄNDER, M. see BREDENKAMP, G.J. and M.S. DEUTSCHLÄNDER. 1995.

DEUTSCHLÄNDER, M. see BREEBAART, L. and M. DEUTSCHLÄNDER. 1997.

DE VOS, V. see HORAK, I.G., V. DE VOS and L.E.O. BRAACK. 1995.

DIPPENAAR-SCHOEMAN, ANNA S., ASTRI LEROY, MARIE DE JAGER and ANNETTE VAN DEN BERG. 1999. A check list of the spider fauna of the Karoo National Park, South Africa (Arachnida: Araneae). Koedoe 42(1): 3142.

DIPPENAAR-SCHOEMAN, A.S. and M.S. HARVEY. 2000. A check list of the pseudoscorpions of South Africa (Arachnida: Pseudoscorpiones). Koedoe 43(2): 89-102.

DOVIE, D. see

SCHOLES, R.J., N. GUREJA, M. GIANNECCHINNI, D. DOVIE, B. WILSON, N. DAVIDSON, K. PIGGOTT, C. MCLOUGHLIN, K. VAN DER VELDE, A FREEMAN, S. BRADLEY, R. SMART and S. NDALA. 2001.

DUDLEY, C.O. 1997. The candelabra tree (Euphorbia ingens): a source of water for black rhinoceros in Liwonde National Park, Malawi. Koedoe 40(1): 57-62.

DUDLEY, C.O. see BHIMA, R. and C.O. DUDLEY. 1997.

DU PLESSIS, W.P. 1997. Refinements to the burning strategy in the Etosha National Park, Namibia. Koedoe 40(1):63-76.

DU PLESSIS, W.P., G.J. BREDENKAMP and W.S.W. TROLLOPE. 1998a. Response of herbaceous species to a degradation gradient in the western region of Etosha National Park, Namibia. Koedoe 41(1): 9-18.

DU PLESSIS, W.P., G.J. BREDENKAMP and W.S.W. TROLLOPE. 1998b. Development of a technique for assessing veld condition in Etosha National Park, Namibia, using key herbaceous species. Koedoe 41(1): 19-30.

DU PREEZ, H.H., M. VAN DER MERWE and J.H.J. VAN VUREN. 1997. Bio-accumulation of selected metals in African sharptooth catfish Clarias gariepinus from the lower Olifants River, Mpumalanga, South Africa. Koedoe 40(1): 77 90.

DU PREEZ, H.H. see

BUERMANN, Y., H.H. DU PREEZ, G.J. STEYN, J.T. HARMSE and A. DEACON. 1995.

DU PREEZ, H.H. see GAGIANO, C.L., G.J. STEYN and H.H. DU PREEZ.

DU PREEZ, H.H. see SEYMORE, T., H.H. DU PREEZ, J.H.J. VAN VUREN, A. DEACON and G. STRYDOM. 1994.

DU PREEZ, H.H. see

SMIT, L., H.H. DU PREEZ and G.J. STEYN. 1998.

DU PREEZ, H.H. see VAN DER MERWE, MARINDA, J.H.J. VAN VUREN and H.H. DU PREEZ. 1993.

DU PREEZ, H.H. see WEPENER, V, N. EULER, J.H.J. VAN VUREN, H.H. DU PREEZ and ASTRI KöHLER. 1992.

DU PREEZ, H.H.see WEPENER, V., J.H.J. VAN VUREN \& H.H. DU PREEZ. 1999.

ECKHARDT, H.C., N. VAN ROOYEN and G.J. BREDENKAMP 1996. The plant communities and species richness of the Alepidea longifoliaMonocymbium ceresiiforme High-altitude Grassland of northern KwaZulu-Natal. Koedoe 39(2): 53-68.

ECKHARDT, H.C., N. VAN ROOYEN and G.J. BREDENKAMP. 1997. Plant communities of the forests, woodlandsand thickets in northern KwZulu-Natal. Koedoe 40(1): 91-112.

ELS, H. and J. DU P. BOTHMA. 2000. Developing partnerships in a paradigm shift to achieve conservation reality in South Africa. Koedoe 43(1): 19-26.

ELS, L.M. and G.I.H. KERLEY. 1996. Biotic and abiotic correlates of small mammal community structure in the Groendal Wilderness Area, Eastern Cape, South Africa. Koedoe 39(2): 121.

ELS, H.J. see ACKERMAN, D.J., A.J. REINECKE and H.J. ELS. 1996a.

ELS, H.J. see ACKERMAN, D.J., A.J. REINECKE and H.J. ELS. 1996b.

ELS, H.J. see ACKERMAN, D.J., A.J. REINECKE and H.J. ELS. 1997a.

ELS, H.J. see ACKERMAN, D.J., A.J. REINECKE and H.J. ELS. 1997b. 
EMSLIE, R.H., see

REILLY, B.K. and R.H. EMSLIE. 1998.

ENGELBRECHT, W.G. and P.T. VAN DER WALT. 1993. Notes on the economic use of the Kruger National Park. Koedoe 36(2): 113-119.

ENGLISH, R.A., M. STALMANS, M.G.L. MILLS and A. VAN WYK. 1993. Helicopter-assisted boma capture of African wild dogs Lycaon pictus. Koedoe 36(1): 103-106.

ENSLIN, B.W., A.L.F. POTGIETER, H.C. BIGGS and R. BIGGS. 2000. Long term effects of fire frequency and season on the woody vegetation dynamics of the Sclerocarya birrea/Acacia nigrescens savanna of the Kruger National Park. Koedoe 43(1): 27-37.

ESSOP, M.F., A.J. HALL-MARTIN and E.H. HARLEY. 1996. Mitochondrial DNA analysis of two southern African elephant populations. Koedoe 39(1): 85-88.

EULER, N. see WEPENER, V, N. EULER, J.H.J. VAN VUREN, H.H. DU PREEZ and ASTRI KöHLER. 1992.

FENTON, M. BROCK.1992. Pelage patterns and crypsis in roosting bats: Taphozous mauritianus and Epomophorus species. Koedoe 35(2): 49-55.

FERGUSON, N.S. see SWANEPOEL, D.G.J., N.S. FERGUSON and M.R. PERRIN. 2000.

FITZPATRICK, M.J. 1994. Range extension of Ceratogyrus sanderi Strand, 1906 (Araneae: Theraphosidae). Koedoe 37(1): 121-122.

FOURIE, J. 1994. Comments on national parks and future relations with neighbouring communities. Koedoe 37(1): 123-136.

FOXCROFT, L.C. and J.H. HOFFMANN. 2000. Dispersal of Dactylopius opuntiae Cockerell (Homoptera: Dactylopiidae), a biological control agent of Opuntia stricta (Haworth.) Haworth. (Cactaceae) in the Kruger National Park. Koedoe 43(2): 1-5.

FREEMAN, A. see

SCHOLES, R.J., N. GUREJA, M. GIANNECCHINNI, D. DOVIE, B. WILSON, N. DAVIDSON, K. PIGGOTT, C. MCLOUGHLIN, K. VAN DER VELDE, A FREEMAN, S. BRADLEY, R. SMART and S. NDALA. 2001.

GAGIANO, C.L., G.J. STEYN and H.H. DU PREEZ. 1996. Tooth replacement of tigerfish Hydrocynus vittatus from the Kruger National Park. Koedoe 39(1): 117-122.

GAYLARD, A. see

WHYTE, I.J., H.C. BIGGS, A. GAYLARD and L.E.O. BRAACK. 1999.

GIANNECCHINNI, M. see

SCHOLES, R.J., N. GUREJA, M. GIANNECCHINNI, D. DOVIE, B. WILSON, N. DAVIDSON, K. PIGGOTT, C. MCLOUGHLIN, K. VAN DER VELDE, A FREEMAN, S. BRADLEY, R. SMART and S. NDALA. 2001.
GRANT, C.C., H.H. MEISSNER and W.A. SCHULTHEISS. 1995. The nutritive value of veld as indicated by faecal phosphorous and nitrogen and its relation to the condition and movement of prominent ruminants during the 1992-1993 drought in the Kruger National Park. Koedoe 38(1):17-31.

GRANT, C.C. and J.L. VAN DER WALT. 2000. Towards an adaptive management approach for the conservation of rare antelope in the Kruger National Park-outcome of a workshop held in May 2000. Koedoe 43(2): 103-112.

GRANT, C.C. see WRENCH, J.M., H.H. MEISSNER, C.C. GRANT and N.H. CASEY. 1996.

GRANT, C.C. see WRENCH, J.M., H.H. MEISSNER and C.C. GRANT. 1997.

GRUBB, P. 1999. Types and type localities of ungulates named from southern Africa. Koedoe 42(2): $13-45$.

GUREJA, N. see SCHOLES, R.J., N. GUREJA, M. GIANNECCHINNI, D. DOVIE, B. WILSON, N. DAVIDSON, K. PIGGOTT, C. MCLOUGHLIN, K. VAN DER VELDE, A FREEMAN, S BRADLEY, R. SMART and S. NDALA. 2001.

HAAGNER, G.V. see BRANCH, W.R. and G.V. HAAGNER. 1992.

HALL-MARTIN, A.J. ESSOP, M.F., A.J. HALL-MARTIN and E.H. HARLEY. 1996.

HARLEY, E.H

ESSOP, M.F., A.J. HALL-MARTIN and E.H. HARLEY. 1996.

HARMSE, J.T. see BUERMANN, Y., H.H. DU PREEZ, G.J. STEYN, J.T. HARMSE and A. DEACON. 1995.

HARRISON, T.D. see WOOD, A.D., S.L. BROUWER, P.D. COWLEY and T.D. HARRISON. 2000.

HARVEY, N.S. see DIPPENAAR-SCHOEMAN, A.S. and M.S. HARVEY. 2000.

HANEKOM, N., J.B. MANN-LANG, B.Q. MANN and T.V.Z. CARINUS. 1997. Shore-angling catches in the Tsitsikamma National Park, 19891995. Koedoe 40(2): 37-56.

HANEKOM, N. see

NOVELLIE, P., H. BIGGS, L. BRAACK, N. HANEKOM, M. KNIGHT, M. MACGREGOR, R. RANDALL, I. RUSSELL and F. VENTER. 1999.

HERITAGE, G.L. and A.W. VAN NIEKERK. 1995. Drought conditions and sediment transport in the Sabie Rivier. Koedoe 38(2): 1-9.

HERITAGE, G.L. and B.P. MOON. 2000. The contemporary geomorphology of the Sabie River in the Kruger National Park. Koedoe 43(1): 39-55. 
HERITAGE, G.L., B.P. MOON, G.P. JEWITT, A.R.G. LARGE and M. ROUNTREE. 2001. The February 2000 floods on the Sabie River, South Africa: an examination of their magnitude and frequency. Koedoe 44(1):37-44.

HERITAGE, G.L. see MOON, B.P. and G.L. HERITAGE. 2001

HEYNE, HELOISE see SPICKETT, A.M., I.G. HORAK, HELOISE HEYNE and L.E.O. BRAACK. 1995.

HEYNS, J. 1994. Description of Longidoroides wiesae spec. nov. from the Kruger National Park (Nematoda: Dorylaimida). Koedoe 37(2): 97104.

HEYNS, J. 2000. The genus Discolaimus in Southern Africa. I. Introduction and redescription of $D$. krugeri Furstenberg \& Heyns, 1966 (Nematoda: Dorylaimida). Koedoe 43(2): 7-15.

HEYNS, J. and ANTOINETTE SWART. 1998. Longidorus jagerae sp.n., another longidorid species with globular inclusions in the prerectum (Nematoda: Longidoridae). Koedoe 41(1): 31-36.

HEYNS, J. see BOTHA, ANNELIZE and J. HEYNS. 1992

HEYNS, J. see BOTHA, ANNELIZE and J. HEYNS. 1993a.

HEYNS, J. see BOTHA, ANNELIZE and J. HEYNS. 1993b.

HISCOCKS, Kay. 1999. The impact of an increasing elephant population on the woody vegetation in southern Sabi Sand Wildtuin, South Africa. Koedoe 42(2): 47-55.

HOFFMAN, M.T. 1993. Major P.J. Pretorius and the decimation of the Addo elephant herd in 19191920: important reassessments. Koedoe 36(2): 23-44.

HOFFMANN, J.H. see FOXCROFT, L.C. and J.H. HOFFMANN. 2000.

HOFFMANN, J.H. see LOTTER, W.D. and J.H. HOFFMANN. 1998.

HORAK, I.G., V. DE VOS and L.E.O. BRAACK. 1995. Arthropod burdens of impalas in the Skukuza region during two droughts in the Kruger National Park. 1995. Koedoe 38(1): 6571.

HORAK, I.G. see

SPICKETT, A.M., I.G. HORAK, HELOISE HEYNE and L.E.O. BRAACK. 1995.

JARDINE, CHRISTINE L. see BEZUIDENHOUT, $\mathrm{H}$. and CHRISTINE L. JARDINE. 2001.

JEWITT, G.P. see

HERITAGE, G.L., B.P. MOON, G.P. JEWITT, A.R.G. LARGE and M. ROUNTREE. 2001.

JORDAAN, J.W. see SCHMIDT, A.G. and J.W. JORDAAN. 1999.

JOUBERT, H. see BREDENKAMP, G.J., H. BEZUIDENHOUT, $\mathrm{H}$. JOUBERT and C. NAUDE. 1994.

KAPPEN, LUDGER see WESSELS, DIRK and LUDGER KAPPEN. 1993.
KARCZMARSKI, L., V.G. COCKCROFT, A MCLACHLAN and P.E.D. WINTER. 1998. Recommendations for the conservation and management of humpback dolphins Sousa chinensis in the Algoa Bay region, South Africa. Koedoe 41(2): 121-129.

KEMP, A.C., K.S. BEGG, G.A. BENN and P. CHADWICK. 1997. A visual assessment of vegetation structure for the Kruger National Park. Koedoe 40(2): 117-121.

KERLEY, G.I.H. see

ELS, L.M. and G.I.H. KERLEY. 1996.

KERLEY, G.I.H. see LANDMAN, M. and G.I.H. KERLEY. 2001.

KERLEY, G.I.H. see PALEY, R.G.T. and G.I.H. KERLEY. 1998.

KNIGHT, ELMINE see AVENANT-OLDEWAGE, ANNEMARIé and ELMINE KNIGHT. 1994.

KNIGHT, M. see NOVELLIE, P., H. BIGGS, L. BRAACK, N. HANEKOM, M. KNIGHT, M. MACGREGOR, R. RANDALL, I. RUSSELL and F. VENTER. 1999.

KOEN, J.H. see ANDERSON, M.D. and J.H. KOEN. 1993.

KÖHLER, ASTRI see

WEPENER, V, N. EULER, J.H.J. VAN VUREN, H.H. DU PREEZ and ASTRI KöHLER. 1992.

KOK, O.B. see

VRAHIMIS, S. and O.B. KOK. 1994.

KUNTZSCH, V. and J.A.J. NEL. 1992. Diet of bateared foxes Otocyon megalotis in the Karoo. Koedoe 35(2): 37-48.

KYLE, R. 2000. Some notes on the occurrence and conservation status of Manis temminckii, the pangolin, in Maputaland, Kwazulu/Natal. Koedoe 43(1): 97-100.

LANDMAN, M. and G.I.H. KERLEY. 2001. Dietary shifts: do grazers become browsers in the Thicket Biome? Koedoe 44(1): 31-36.

LARGE, A.R.G. see HERITAGE, G.L., B.P. MOON, G.P. JEWITT, A.R.G. LARGE and M. ROUNTREE. 2001.

LE RICHE, E.A.N. see BOTHMA, J. DU P. and E.A.N. LE RICHE. 1993.

LE RICHE, E.A.N. see BOTHMA J. du P. and E.A.N. LE RICHE. 1994.

LE RICHE, E.A.N. see BOTHMA, J. DU P., S. VAN HOVEN and E.A.N. LE RICHE. 1993.

LE RICHE, E.A.N. see BOTHMA J. du P., N. VAN ROOYEN and E.A.N. LE RICHE. 1997.

LEROY, ASTRI see DIPPENAAR-SCHOEMAN, ANNA S., ASTRI LEROY, MARIE DE JAGER and ANNETTE VAN DEN BERG. 1999. 
LOADER, J.A. 1994. National Parks and social involvement - an argument. Koedoe 37(1): 137148.

LOTTER, W.D. and J.H. HOFFMANN. 1998. An integrated management plan for the control of Opuntia stricta (cactaceae) in the Kruger National Park, South Africa. Koedoe 41(1): 63-68.

LOTTER, W.D., L. THATCHER, L. ROSSOUW and C.F. REINHARDT. 1999. The influence of baboon predation and time in water on germination and early establishment of Opuntia stricta (Australian pest pear) in the Kruger National Park. Koedoe 42(1): 43-50.

LUUS-POWELL, WILMIEN and ANNEMARIÉ AVENANT-OLDEWAGE. 1996. Surface morphology of Chonopeltis victori Avenant-Oldewage, 1991, and aspects of the histomorphology. Koedoe 39(1): 55-70.

MACGREGOR, M. see NOVELLIE, P., H. BIGGS, L. BRAACK, N. HANEKOM, M. KNIGHT, M. MACGREGOR, R. RANDALL, I. RUSSELL and F. VENTER. 1999.

MANN, B.Q. and C.D. BUXTON. 1992. Diets of Diplodus sargus capensis and D. cervinus hottentotus (Pisces: Sparidae) on the Tsitsikamma coast, South Africa. Koedoe 35(2): 27-36.

MANN, B.Q. see

HANEKOM, N., J.B. MANN-LANG, B.Q. MANN and T.V.Z. CARINUS. 1997.

MANN-LANG, J.B. see

HANEKOM, N., J.B. MANN-LANG, B.Q. MANN and T.V.Z. CARINUS. 1997.

MARÉ, N. see

SOLOMON, M., N. ZAMBATIS, H.C. BIGGS and N. MARÉ. 1999.

MARX, H.M. and A. AVENANT-OLDEWAGE. 1998. A further investigation into the bioaccumulation of lead and zinc in the organs and tissues of the African sharptooth catfish, Clarias gariepinus from two localities in the Olifants River, Kruger National Park. Koedoe 41(2): 27-43.

MARX, HAZEL see AVENANT-OLDEWAGE, ANNEMARIÉ and HAZEL MARX. 2000.

MATTHEWS, W.S. G.J. BREDENKAMP and N. VAN ROOYEN. 1994. The phytosociology and syntaxonomy of relatively low-altitude areas in the North-eastern Mountain Sourveld, in the eastern Transvaal escarpment region. Koedoe 37(2): 73-88.

MCLACHLAN, A. see

KARCZMARSKI, L., V.G. COCKCROFT, A. MCLACHLAN and P.E.D. WINTER.

MCLOUGHLIN, C. see

SCHOLES, R.J., N. GUREJA, M. GIANNECCHINNI, D. DOVIE, B. WILSON, N. DAVIDSON, K. PIGGOTT, C. MCLOUGHLIN, K. VAN DER VELDE, A FREEMAN, S. BRADLEY, R. SMART and S. NDALA. 2001.
MEISSNER, H.H. see

GRANT, C.C., H.H. MEISSNER and W.A. SCHULTHEISS. 1995.

MEISSNER, H.H. see WRENCH, J.M., H.H. MEISSNER, C.C. GRANT and N.H. CASEY. 1996.

MEISSNER, H.H. see

WRENCH, J.M., H.H. MEISSNER and C.C. GRANT. 1997.

MEYER, V.W., L.E.O. BRAACK and H.C. BIGGS. 2000. Distribution and density of Cubitermes Wasmann (Isoptera: Termitidae) mounds in the northern Kruger National Park. Koedoe 43(1): 57-65.

MILLS, M.G.I. 1995. Notes on wild dog Lycaon pictus and lion Panthera leo population trends during a drought in the Kruger National Park. Koedoe 38(1): 95-99.

MILLS, M.G.L. see ENGLISH, R.A., M. STALMANS, M.G.L. MILLS and A. VAN WYK. 1993.

MOLL, EUGENE. 2001. Comments on the article Technology for alignment of participants in nature conservation: a case study at the Southern African Wildlife College by I.P. Sonnekus and G.J. Breytenbach-Koedoe 43/2 (2000). Koedoe 44(1): 125-127.

MONADJEM, A. 1998. Distributional patterns and conservation status of mammals of Swaziland, southern Africa. Koedoe 41(2): 45-59.

MOON, B.P. and G.L. HERITAGE. 2001. The contemporary geomorphology of the Letaba River in the Kruger National Park. Koedoe 44(1): 45-55.

MOON, B.P. see HERITAGE, G.L. and B.P. MOON. 2000.

MOON, B.P. see

HERITAGE, G.L., B.P. MOON, G.P. JEWITT, A.R.G. LARGE and M. ROUNTREE. 2001.

MOUTON, P. LE F.N. and J.H. VAN WYK. 1993. Reptile fauna of the Katse Dam catchment area and a biogeographical assessment of species composition in the Lesotho Highlands. Koedoe 36(1): 67-78.

MWIMA, H.K. 2001. A brief history of Kafue National Park, Zambia. Koedoe 44(1): 57-72.

NAUDE, C. see

BREDENKAMP, G.J., H. BEZUIDENHOUT, H. JOUBERT and C. NAUDE. 1994.

NDALA, S. see

SCHOLES, R.J., N. GUREJA, M. GIANNECCHINNI, D. DOVIE, B. WILSON, N. DAVIDSON, K. PIGGOTT, C. MCLOUGHLIN, K. VAN DER VELDE, A FREEMAN, S. BRADLEY, R. SMART and S. NDALA. 2001.

NEL, J.G. see BANCROFT, C.M., H. BEZUIDENHOUT and J.G. NEL. 1998.

NEL, J.A.J. see

KUNTZSCH, V. and J.A.J. NEL. 1992.

NEWBERY, CHRISTIA H. 1999. A key to the Soricidae, Macroscelididae, Gliridae and Muridae of 
Gauteng, North West Province, Mpumalanga and the Northern Province, South Africa. Koedoe 42(1): 51-55.

NOVELLIE, P.A. 1994. Monitoring the condition of mountain zebra habitat in the Mountain Zebra National Park. Koedoe 37(1): 35-39.

NOVELLIE, P.A. and M. KNIGHT. 1994. Repatriation and translocation of ungulates into South African national parks: an assessment of past attempts. Koedoe 37(1): 115-119.

NOVELLIE, P., H. BIGGS, L. BRAACK, N. HANEKOM, M. KNIGHT, M. MACGREGOR, R. RANDALL, I. RUSSELL and F. VENTER. 1999. Peripheral development: position paper for the Directorate of the South African National Parks. Koedoe 42(2): 113-116.

NOVELLIE, P. and A. WINKLER. 1993. A simple index of habitat suitability for Cape mountain zebras. Koedoe 36(2): 53-59.

OLIVIER, P.A.S. and J.P. VAN NIEKERK. 1995. New morphological information on the parasitic copepod Lernanthropus sarbae Kensley \& Grindley, 1973 (Copepoda: Lernanthropidae) from Lake St. Lucia, South Africa, using scanning electron microscopy. Koedoe 38(2): 99-104.

OLIVIER, P.A.S. and P.D. THERON. 1997. The genus Eupodes Koch, 1835 (Acari: Prostigmata: Eupodidae) from southern African soil and vegetation. Part 1. Characterisation of the genus, designation of the type species and descriptions of three new species. Koedoe 40(2): 57-73.

OSBORN, R. see

SAMWAYS, M.J., R. OSBORN and I. VAN HEERDEN. 1996.

OWEN-SMITH, N. see

WINKLER, A. and N. OWEN-SMITH. 1995.

PALEY, R.G.T. and G.I.H. KERLEY. 1998. The winter diet of elephant in Eastern Cape Subtropical Thicket, Addo Elephant National Park. Koedoe 41(1): 37-46.

PALMER, A.R. see RUBIN, FRANCINE and A.R. PALMER. 1996.

PARR, C.L. and B.H. BROCKETT. 1999. Patchmosaic burning: a new paradigm for savanna fire management in protected areas? Koedoe 42(2): 117-130.

PELSER, ANTON J. see VAN VOLLENHOVEN, ANTON C., ANTON J. PELSER \& JAN W. VAN DEN BOS. 1998.

PENZHORN, B.L. and N.J. VAN DER MERWE. 1993. Testis size and spermatogenesis of tsessebes from Nylsvley Nature Reserve, Transvaal. Koedoe 36(1): 95-98.

PERRIN, M.R. see SWANEPOEL, D.G.J., N.S. FERGUSON and M.R. PERRIN. 2000.

PIENAAR, D. J., J. DU P. BOTHMA and G. K. THERON. 1993. Landscape preference of the white rhinoceros in the central and northern Kruger National Park. Koedoe 36(1): 79-86.
PIENAAR, D. see

TROLLOPE, W.S.W., L.A. TROLLOPE, H.C. BIGGS, D. PIENAAR and A.L.F. POTGIETER. 1998.

PIGGOTT, K. see

SCHOLES, R.J., N. GUREJA, M. GIANNECCHINNI, D. DOVIE, B. WILSON, N. DAVIDSON, K. PIGGOTT, C. MCLOUGHLIN, K. VAN DER VELDE, A FREEMAN, S. BRADLEY, R. SMART and S. NDALA. 2001.

PLUG, C. and I. PLUG. 1997. Popups on Moon Rock, Augrabies Falls National Park. Koedoe 40(2): 75-84.

PLUG, I. 1993. The macrofaunal remains of wild animals from Abbot's Cave and Lame Sheep Shelter, Seacow Valley, Cape. Koedoe 36(1): 1526.

PLUG, I. see PLUG, C. and I. PLUG. 1997.

POTGIETER, A.L.F. see BIGGS, H.C. and A.L.F. POTGIETER. 1999.

POTGIETER, A.L.F. see

ENSLIN, B.W., A.L.F. POTGIETER, H.C. BIGGS and R. BIGGS. 2000.

POTGIETER, A.L.F. see TROLLOPE, W.S.W., L.A. TROLLOPE, H.C. BIGGS, D. PIENAAR and A.L.F. POTGIETER. 1998.

POTGIETER, A.L.F. see VAN WILGEN, B.W., H.C. BIGGS and A.L.F. POTGIETER. 1998.

PRETORIUS, B.P. see PRETORIUS, QUARTA, B.P. PRETORIUS and C.S. DANNHAUSER. 1996.

PRETORIUS, QUARTA, B.P. PRETORIUS and C.S. DANNHAUSER. 1996. The reproductive behaviour of the suni Neotragus moschatus zuluensis in captivity. Koedoe 39(1): 123-126.

RANDALL, R. see

NOVELLIE, P., H. BIGGS, L. BRAACK, N. HANEKOM, M. KNIGHT, M. MACGREGOR, R. RANDALL, I. RUSSELL and F. VENTER. 1999.

RASA, O.A.E. 1994. Behavioural adaptations to moisture as an environmental constraint in a nocturnal burrow-inhabiting Kalahari detritivore Parastizopus armaticeps Peringuey (Coleoptera: Tenebrionidae). Koedoe 37(1): 57-66.

RASMUSSEN, G.S.A. 1996. Predation on bat-eared foxes Otocyon megalotis by Cape hunting dogs Lycaon pictus. Koedoe 39(1): 127-134.

RAUBENHEIMER, E.J. 1999. Morphological aspect and composition of African elephant (Loxodonta africana) ivory. Koedoe 42(2): 57-64.

RAUBENHEIMER, E.J. 2000. Development of the tush and tusk and tusklessness in the African elephant (Loxodonta africana). Koedoe 43(2): 57-64.

RAUTENBACH, I.L., G.N. BRONNER, and D.A. SCHLITTER. 1993. Karyotypic data and atten- 
dant systematic implications for the bats of southern Africa. Koedoe 36(2): 87-104.

REILLY, B.K. and R.H. EMSLIE. 1998. Power and precision of replicated helicopter surveys in mixed bushveld. Koedoe 41(1): 47-56.

REINECKE, A.J. see ACKERMAN, D.J., A.J. REINECKE and H.J. ELS. 1996a.

REINECKE, A.J. see ACKERMAN, D.J., A.J. REINECKE and H.J. ELS. 1996b.

REINECKE, A.J. see ACKERMAN, D.J., A.J. REINECKE and H.J. ELS. 1997a.

REINECKE, A.J. see ACKERMAN, D.J., A.J. REINECKE and H.J. ELS. 1997b.

REINHARDT, C.F. 2000. Weed management practices in natural ecosystems: a critical overview. Koedoe 43(1): 67-74.

REINHARDT, C.F. see LOTTER, W.D., L. THATCHER, L. ROSSOUW and C.F. REINHARDT. 1999.

RÖSCH, HELGA. 2001. The identification and description of the management units of the Goegap Nature Reserve. Koedoe 44(1): 17-30.

ROSSOUW, L. see

LOTTER, W.D., L. THATCHER, L. ROSSOUW and C.F. REINHARDT. 1999.

ROUNTREE, M. see

HERITAGE, G.L., B.P. MOON, G.P. JEWITT, A.R.G. LARGE and M. ROUNTREE. 2001.

RUBIN, FRANCINE and A.R. PALMER. 1996. The physical environment and major plant communities of the Karoo National Park, South Africa. Koedoe 39(2): 25-52.

RUSSELL, I.A. 1996. Water quality in the Knysna estuary. Koedoe 39(1): 1-8.

RUSSELL, I.A. 1997. Spatial variation in the structure of fish assemblages in the Vaalbos National Park. Koedoe 40(1): 113-123.

RUSSELL, I.A. 1999a. Changes in the water quality of the Wilderness and Swartvlei lake systems, South Africa. Koedoe 42(1): 57-72.

RUSSELL, I.A. 1999b. Freshwater fish of the Wilderness National Park. Koedoe 42(1): 73-78.

RUSSELL, I. see

NOVELLIE, P., H. BIGGS, L. BRAACK, N. HANEKOM, M. KNIGHT, M. MACGREGOR, R. RANDALL, I. RUSSELL and F. VENTER. 1999.

SAMWAYS, M.J., R. OSBORN and I. VAN HEERDEN. 1996. Distribution of benthic invertebrates at different depths in a shallow reservoir in the KwaZulu-Natal Midlands. Koedoe 39(2): 69-76.

SCHLITTER, D.A. see

RAUTENBACH, I.L., G.N. BRONNER, and D.A. SCHLITTER. 1993.

SCHMIDT, A.G. and J.W. JORDAAN. 1999. An approach to assessing the financial viability of bush clearing on game ranches in savanna regions. Koedoe 42(2): 65-72.
SCHMIDT, A.G., G.K. THERON and W. VAN HOVEN. 1995. A comparison of some methods used to estimate the grazing capacity of a game ranch in Northern Province, South Africa. Koedoe 38(2): 123-128.

SCHOLES, R.J., N. GUREJA, M. GIANNECCHINNI, D. DOVIE, B. WILSON, N. DAVIDSON, K. PIGGOTT, C. MCLOUGHLIN, K. VAN DER VELDE, A FREEMAN, S. BRADLEY, R. SMART and S. NDALA. 2001. The environment and vegetation of the flux measurement site near Skukuza, Kruger National Park. Koedoe 44(1): 73-83.

SCHOLES, R.J. see

SHACKLETON, C.M. and R.J. SCHOLES. 2000.

SCHULTHEISS, W.A. see

GRANT, C.C., H.H. MEISSNER and W.A. SCHULTHEISS. 1995.

SEYMORE, T., H.H. DU PREEZ, J.H.J. VAN VUREN, A. DEACON and G. STRYDOM. 1994. Variations in selected water quality variables and metal concentrations in the sediment of the lower Olifants and Selati rivers, South Africa. Koedoe 37(2): 1-18.

SHACKLETON, C.M. and R.J. SCHOLES. 2000. Impact of fire frequency on woody community structure and soil nutrients in the Kruger National Park. Koedoe 43(1): 75-81.

SLOTOW, R. and G. VAN DYK. 2001. Role of delinquent young "orphan" male elephants in high mortality of white rhinoceros in Pilanesberg National Park, South Africa. Koedoe 44(1): 85-94.

SMART, R. see

SCHOLES, R.J., N. GUREJA, M. GIANNECCHINNI, D. DOVIE, B. WILSON, N. DAVIDSON, K. PIGGOTT, C. MCLOUGHLIN, K. VAN DER VELDE, A FREEMAN, S. BRADLEY, R. SMART and S. NDALA. 2001.

SMIT, C.M., G.J. BREDENKAMP, N. VAN ROOYEN, A.E. VAN WYK and J.M. COMBRINCK. 1997. Vegetation of the Witbank Nature Reserve and its importance for conservation of threatened Rocky Highveld Grassland. Koedoe 40(2): 85-104.

SMIT, L., H.H. DU PREEZ and G.J. STEYN. 1998. Influence of natural silt on the survival of Oreochromis mossambicus yolk sac larvae. Koedoe 41(1): 57-62.

SOLOMON, M., N. ZAMBATIS, H.C. BIGGS and N. MARÉ. 1999. Comparison of classifications commonly used as templates for management, scientific and GIS work in the Kruger National Park. Koedoe 42(2): 131-142.

SONNEKUS, I.P. and G.J. BREYTENBACH. 2000. Technology for alignment of participants in nature conservation: a case study at the Southern African Wildlife College. Koedoe 43(2): 65-88. 
SONNEKUS, I.P. and G.J. BREYTENBACH. 2001a. Conservation business: sustaining Africa's future. Koedoe 44(1): 105-124.

SONNEKUS, I.P. and G J BREYTENBACH. 2001 b. Reply to the comments from the Southern African Wildlife College (SAWC). Koedoe 44(1): 128.

SPICKETT, A.M., I.G. HORAK, HELOISE HEYNE and L.E.O. BRAACK. 1995. The effect of severe drought on the abundance of ticks on vegetation and on scrub hares in the Kruger National Park. 1995. Koedoe 38(1): 59-64.

STALMANS, M. see

ENGLISH, R.A., M. STALMANS, M.G.L. MILLS and A. VAN WYK. 1993.

STALMANS, M. see STEYN, A. and M. STALMANS. 2001.

STEYN, A. and M. STALMANS. 2001. Selective habitat utilisation and impact on vegetation by African elephant within a heterogeneous landscape. Koedoe 44(1): 95-103.

STEYN, G.J. see BUERMANN, Y., H.H. DU PREEZ, G.J. STEYN, J.T. HARMSE and A. DEACON. 1995.

STEYN, G.J. see

GAGIANO, C.L., G.J. STEYN and H.H. DU PREEZ.

STEYN, G.J. see

SMIT, L., H.H. DU PREEZ and G.J. STEYN. 1998.

STRYDOM, G. see

SEYMORE, T., H.H. DU PREEZ, J.H.J. VAN VUREN, A. DEACON and G. STRYDOM. 1994.

SWANEPOEL, D. G. J. 1996. Identification of the Nile crocodile Crocodylus niloticus by the use of natural tail marks. Koedoe 39(1): 113-116.

SWANEPOEL, D.G.J., N.S. FERGUSON and M.R. PERRIN. 2000. Nesting ecology of Nile crocodiles (Crocodylus niloticus) in the Olifants River, Kruger National Park. Koedoe 43(2): 35-46.

SWART, ANTOINETTE, see HEYNS, J. and ANTOINETTE SWART. 1998.

THATCHER, L. see

LOTTER, W.D., L. THATCHER, L. ROSSOUW and C.F. REINHARDT. 1999.

THERON, G.K. see

BEZUIDENHOUT, H., G.J. BREDENKAMP and G.K. THERON. 1994.

THERON, G.K. see PIENAAR, D. J., J. DU P. BOTHMA and G. K. THERON. 1993.

THERON, G.K. see SCHMIDT, A.G., G.K. THERON and W. VAN HOVEN. 1995.

THERON, G.K.see THRASH, I., G.K. THERON and J. DU P. BOTHMA. 1993.

THERON, P.D. see

OLIVIER, P.A.S. and P.D. THERON. 1997.
THRASH, I. 1998. Association of three succulent plant species with woody canopy in the mixed bushveld, South Africa. Koedoe 41(2): 95-101.

THRASH, I. and J.F. DERRY. 1999. The nature and modelling of piospheres: a review. Koedoe 42(2): 73-94.

THRASH, I., G.K. THERON and J. DU P. BOTHMA. 1993. Herbivore dung deposit counts around drinking troughs in the Kruger National Park. Koedoe 36(1): 87-94.

TROLLOPE, L.A. see TROLLOPE, W.S.W., L.A. TROLLOPE, H.C. BIGGS, D. PIENAAR and A.L.F. POTGIETER. 1998.

TROLLOPE, W.S.W. 1993. Fire regime of the Kruger National Park for the period 1980 - 1992. Koedoe 36(2): 45-52.

TROLLOPE, W.S.W., L.A. TROLLOPE, H.C. BIGGS, D. PIENAAR and A.L.F. POTGIETER. 1998. Long term changes in the woody vegetation of the Kruger National Park, with special reference to the effects of elephants and fire. Koedoe 41(2): 103-112.

TROLLOPE, W.S.W. . see

DU PLESSIS, W.P., G.J. BREDENKAMP and W.S.W. TROLLOPE. 1998a.

TROLLOPE, W.S.W. . see

DU PLESSIS, W.P., G.J. BREDENKAMP and W.S.W. TROLLOPE. 1998b.

VAN DEN BERG, ESTHER. 1993. A first list of plant-parasitic nematodes from the Wilderness National Park, with a description of Ogma sekgwaum spec. nov. Koedoe 36(2): 61-76.

VAN DEN BERG, ESTHER. 1996. A first list of plant-parasitic nematodes from the Tsitsikamma National Park, with descriptions of two new species of the subfamily Criconematinae. Koedoe 39(1): 43-54.

VAN DEN BERG, A. and A.S. DIPPENAARSCHOEMAN, 1994. A revision of the Afrotropical species of the genus Tibellus Simon (Araneae: Philodromidae). Koedoe 37(1): 67114.

VAN DEN BERG, ANNETTE see DIPPENAAR-SCHOEMAN, ANNA S., ASTRI LEROY, MARIE DE JAGER and ANNETTE VAN DEN BERG. 1999.

VAN DEN BOS, JAN W. see VAN VOLLENHOVEN, ANTON C., ANTON J. PELSER \& JAN W. VAN DEN BOS. 1998.

VAN DER MERWE, MARINDA, J.H.J. VAN VUREN and H.H. DU PREEZ. 1993. Lethal copper concentration levels for Clarias gariepinus (Burchell, 1822) a preliminary study. Koedoe 36(2): 77-86.

VAN DER MERWE, M. see

DU PREEZ, H.H., M. VAN DER MERWE and J.H.J. VAN VUREN. 1997.

VAN DER VELDE, K. see

SCHOLES, R.J., N. GUREJA, M. GIANNECCHINNI, D. DOVIE, B. WILSON, N. DAVIDSON, K. PIGGOTT, C. MCLOUGHLIN, 
K. VAN DER VELDE, A FREEMAN, S BRADLEY, R. SMART and S. NDALA. 2001.

VAN DER WAAL, B.C.W. 1998. Survival strategies of sharptooth catfish Clarias gariepinus in desiccating pans in the northern Kruger National Park. Koedoe 41(2): 131-138.

VAN DER WALT, P.T. see ENGELBRECHT, W.G. and P.T. VAN DER WALT. 1993.

VAN DER WALT, J.L. see GRANT, C.C. and J.L. VAN DER WALT. 2000.

VAN DIJK, D.E. 1996. Anuran fauna of the Lesotho Highlands in the Khatse Dam catchment area and Jorodane River region. Koedoe 39(2): 77-90.

VAN DYK, G. see SLOTOW, R. and G. VAN DYK. 2001.

VAN HEERDEN, I. see SAMWAYS, M.J., R. OSBORN and I. VAN HEERDEN. 1996.

VAN HOVEN, S. see BOTHMA, J. DU P., S. VAN HOVEN and E.A.N. LE RICHE. 1993.

VAN HOVEN, W. see SCHMIDT, A.G., G.K. THERON and W. VAN HOVEN. 1995.

VAN NIEKERK, A.W. see HERITAGE, G.L. and A.W. VAN NIEKERK. 1995.

VAN NIEKERK, J.P. see OLIVIER, P.A.S. and J.P. VAN NIEKERK. 1995.

VAN ROOYEN, N. and H. BEZUIDENHOUT. 1997. New records of flowering plants and ferns from the Kalahari Gemsbok National Park. Koedoe 40(2): 105-116.

VAN ROOYEN, N. see

BOTHMA J. du P., N. VAN ROOYEN and E.A.N. LE RICHE. 1997.

VAN ROOYEN, N. see

BRITS, J, M.W. VAN ROOYEN and N. VAN ROOYEN. 2000.

VAN ROOYEN, N. see

BROWN, L.R., G.J. BREDENKAMP and N. VAN ROOYEN. 1995.

VAN ROOYEN, N. see BROWN, L.R., G.J. BREDENKAMP and N. VAN ROOYEN. 1996

VAN ROOYEN, N. see ECKHARDT, H.C., N. VAN ROOYEN and G.J. BREDENKAMP 1996.

VAN ROOYEN, N. see ECKHARDT, H.C., N. VAN ROOYEN and G.J. BREDENKAMP. 1997.

VAN ROOYEN, N. see MATTHEWS, W.S. G.J. BREDENKAMP and N. VAN ROOYEN. 1994.

VAN ROOYEN, N. see SMIT, C.M., G.J. BREDENKAMP, N. VAN ROOYEN, A.E. VAN WYK and J.M. COMBRINCK. 1997.

VAN VOLLENHOVEN, ANTON C., ANTON J. PELSER \& JAN W. VAN DEN BOS. 1998. A historical-archaeological investigation of an
Anglo-Boer War British outpost in the Kruger National Park. Koedoe 41(2): 113-120.

VAN VUREN, J.H.J. see

DU PREEZ, H.H., M. VAN DER MERWE and J.H.J. VAN VUREN. 1997.

VAN VUREN, J.H.J. see

VAN DER MERWE, MARINDA, J.H.J. VAN VUREN and H.H. DU PREEZ. 1993.

VAN VUREN, J.H.J. see

SEYMORE, T., H.H. DU PREEZ, J.H.J. VAN VUREN, A. DEACON and G. STRYDOM. 1994.

VAN VUREN, J.H.J. see

WEPENER, V, N. EULER, J.H.J. VAN VUREN, H.H. DU PREEZ and ASTRI KöHLER. 1992.

VAN VUREN, J.H.J. see WEPENER, V., J.H.J. VAN VUREN \& H.H. DU PREEZ. 1999.

VAN WILGEN, B.W., H.C. BIGGS and A.L.F. POTGIETER. 1998. Fire management and research in the Kruger National Park, with suggestions on the detection of thresholds of potential concern. Koedoe 41(1): 69-87.

VAN WYK, E. see

CILLIERS, S.S., E. VAN WYK and G.J BREDENKAMP. 1999.

VAN WYK, A. see ENGLISH, R.A., M. STALMANS, M.G.L. MILLS and A. VAN WYK. 1993.

VAN WYK, J.H. see MOUTON, P. LE F.N. and J.H. VAN WYK. 1993.

VAN WYK, A.E. see

SMIT, C.M., G.J. BREDENKAMP, N. VAN ROOYEN, A.E. VAN WYK and J.M. COMBRINCK. 1997.

VENTER, F. see

NOVELLIE, P., H. BIGGS, L. BRAACK, N. HANEKOM, M. KNIGHT, M. MACGREGOR, R. RANDALL, I. RUSSELL and F. VENTER. 1999.

VENTER, D. see

WESSELS, D., D. VENTER, W. WESSELS and L. WESSELS. 1995.

VILJOEN, A.J. 1995. The influence of the 1991/92 drought on the woody vegetation of the Kruger National Park. Koedoe 38(2): 85-97.

VILJOEN, P.C. 1995. Changes in number and distribution of hippopotamus (Hippopotamus amphibius) in the Sabie River, Kruger National Park, during the 1992 drought. Koedoe 38(2): 115-121.

VILJOEN, P.C. and P.F. RETIEF. 1994. The use of the Global Positioning System for real-time data collecting during ecological aerial surveys in the Kruger National Park, South Africa. Koedoe 37(1): 149-157.

VISSER, N., W. VAN HOVEN and G.K. THERON. 1996. The vegetation and identification of management units of the Honnet Nature Reserve, 
Northern Province, South Africa. Koedoe 39(1): 25-42.

VRAHIMIS, S. and O.B. KOK. 1994. Notes on the diurnal activity of early post-natal black wildebeest calves. Koedoe 37(2): 109-113.

WATSON, L.H. 1999. Eland browsing of Grewia occidentalis in semi-arid shrubland: the influence of bush clumps. Koedoe 42(1): 79-84.

WEBLEY, LITA, FIONA ARCHER and J. BRINK. 1993. Die Toon: a Late Holocene site in the Richtersveld National Park, northern Cape. Koedoe 36(2): 1-9.

WEPENER, V., J.H.J. VAN VUREN \& H.H. DU PREEZ. 1999. The implementation of an aquatic toxicity index as a water quality monitoring tool in the Olifants River (Kruger National Park). Koedoe 42(1): 85-96.

WESSELS, DIRK and LUDGER KAPPEN. 1993. Photosynthetic performance of rock-colonising lichens in the Mountain Zebra National Park, South Africa. Koedoe 36(1): 27-48.

WESSELS, D., D. VENTER, W. WESSELS and L. WESSELS. 1995. Experimental strain analysis of Clarens Sandstone colonised by endolithic lichens. Koedoe 38(2): 35-47.

WESSELS, L. see WESSELS, D., D. VENTER, W. WESSELS and L. WESSELS. 1995.

WESSELS, W. see WESSELS, D., D. VENTER, W. WESSELS and L. WESSELS. 1995.

WEPENER, V, N. EULER, J.H.J. VAN VUREN, H.H. DU PREEZand ASTRI KÖHLER. 1992. The development of an aquatic toxicity index as a tool in the operational management of water quality in the Olifants River (Kruger National Park). Koedoe 35(2): 1-9.

WHYTE, I.J., H.C. BIGGS, A. GAYLARD and L.E.O. BRAACK. 1999. A new policy for the management of the Kruger National Park's elephant population. Koedoe 42(1): 111-132.

WILSON, B. see

SCHOLES, R.J., N. GUREJA, M. GIANNECCHINNI, D. DOVIE, B. WILSON, N. DAVIDSON, K. PIGGOTT, C. MCLOUGHLIN, K. VAN DER VELDE, A FREEMAN, S. BRADLEY, R. SMART and S. NDALA. 2001.
WINKLER, A. and N. OWEN-SMITH. 1995. Habitat utilisation by Cape mountain zebras in the Mountain Zebra National Park. Koedoe 38(1): 83-93.

WINKLER, A. see NOVELLIE, P. and A. WINKLER. 1993.

WINTER, P.E.D. see KARCZMARSKI, L., V.G. COCKCROFT, A. MCLACHLAN and P.E.D. WINTER.

WOLMARANS,. C.T. see

DE KOCK, K.N. and C.T. WOLMARANS. 1998.

WOOD, A.D., S.L. BROUWER, P.D. COWLEY and T.D. HARRISON. 2000. An updated check list of the ichthyofaunal species assemblage of the Tsitsikamma National Park, South Africa. Koedoe 43(1): 83-95.

WOODD, A.M. 1999. A demographic model to predict future growth of the Addo elephant population. Koedoe 42(1): 79-100.

WRENCH, J.M., H.H. MEISSNER, C.C. GRANT and N.H. CASEY. 1996. Environmental factors that affect the concentration of $\mathrm{P}$ and $\mathrm{N}$ in faecal samples collected for the determination of nutritional status. Koedoe 39(2): 1-6.

WRENCH, J.M., H.H. MEISSNER and C.C. GRANT. 1997. Assessing diet quality of African ungulates from faecal analyses: the effect of forage quality, intake and herbivore species. Koedoe 40(1): 125-136.

ZAMBATIS, N and H.C. BIGGS. 1995. Rainfall and temperatures during the 1991/92 drought in the Kruger National Park. Koedoe 38(1): 1-16.

ZAMBATIS, N. see SOLOMON, M., N. ZAMBATIS, H.C. BIGGS and N. MARÉ. 1999.

ZIEGER, U. see CAULDWELL, A.E., U.ZIEGER, M.G. BINGHAM and G.J. BREDENKAMP. 1998.

ZIETSMAN, P.C. and H. BEZUIDENHOUT. 1999. Flowering plant biodiversity of Augrabies Falls National Park: a comparison between Augrabies Falls National Park, Kalahari Gemsbok National Park, Vaalbos National Park and Goegap Nature Reserve. Koedoe 42(2): 95-112. 


\section{Botany}

BANCROFT, C.M., H. BEZUIDENHOUT and J.G. NEL. 1998. Use of veld condition assessment to set objectives and targets for an ISO 14001 environmental management system for Vaalbos National Park. Koedoe 41(2): 1-12.

BEZUIDENHOUT, H. 1994. An ecological study of the major vegetation communities of the Vaalbos National Park, Northern Cape. 1. The ThanDroogeveld section. Koedoe 37(2): 19-44.

BEZUIDENHOUT, H. 1995. An ecological study of the major vegetation communities of the Vaalbos National Park, Northern Cape. 2. The GraspanHolpan section. Koedoe 38(2): 65-83.

BEZUIDENHOUT, $\mathrm{H}$. 1996. The major vegetation communities of the Augrabies Falls National Park, Northern Cape. 1. The southern section. Koedoe 39(2): 7-24.

BEZUIDENHOUT, $\mathrm{H}$. and CHRISTINE L. JARDINE. 2001. A reconnaissance botanical survey of the Lower Orange River (Blouputs to Onseepkans) in the Northern Cape, South Africa. Koedoe 44(1): 1-8.

BEZUIDENHOUT, H., G.J. BREDENKAMP and G.K. THERON. 1994. Phytosociological classes of the western Transvaal grassland, South Africa. Koedoe 37(1): 1-18.

BEZUIDENHOUT, H., H.C. BIGGS and G.J. BREDENKAMP. 1996. A process supported by the utility BBPC for analysing Braun-Blanquet data on a personal computer. Koedoe 39(1): 107-112.

BREDENKAMP, G.J. and H. BEZUIDENHOUT. 1995. A proposed procedure for the analysis of large phytosociological data sets in the classification of South African grasslands. Koedoe 38(1): 33-39.

BREDENKAMP, G.J., H. BEZUIDENHOUT, H. JOUBERT and C. NAUDE. 1994. The vegetation of the Boskop Dam Nature Reserve, Potchefstroom. Koedoe 37(1): 19-33.

BREDENKAMP, G.J. and M.S. DEUTSCHLÄNDER. 1994. The Themedo triandrae - Setarietum incrassatae, a new association from gabbro in the Manyeleti Game Reserve, Gazankulu, South Africa. Koedoe 37(2): 45-58.

BREDENKAMP, G.J. and M.S. DEUTSCHLÄNDER. 1995. New azonal syntaxa from the hills and river banks of the Manyeleti Game Reserve, Northern Transvaal Province, South Africa. Koedoe 38(1): 41-58.

BREEBAART, L. and M. DEUTSCHLÄNDER. 1997. The vegetation types and management units of Goedverwacht farm in the mixed bushveld of the Northern Province, South Africa. Koedoe 40(2): 19-35.

BRITS, J, M.W. VAN ROOYEN and N. VAN ROOYEN. 2000. Technique to study the impact of large herbivores on woody vegetation within piospheres. Koedoe 43(2): 47-56.

BROWN, L.R. and H. BEZUIDENHOUT. 2000. The phytosociology of the De Rust section of the Mountain Zebra National Park, Eastern Cape. Koedoe 43(1): 1-18.

BROWN, L.R. and G.J. BREDENKAMP. 1994. The phytosociology of the southern section of Borakalalo Nature Reserve, South Africa. Koedoe 37(2): 59-72.

BROWN, L.R., G.J. BREDENKAMP and N. VAN ROOYEN. 1995. The phytosociology of the western section of Borakalalo Nature Reserve. Koedoe 38(2): 49-64.

BROWN, L.R., G.J. BREDENKAMP and N. VAN ROOYEN. 1996. The phytosociology of the northern section of the Borakalalo Nature Reserve. Koedoe 39(1): 9-24.

CAULDWELL, A.E., U.ZIEGER, M.G. BINGHAM and G.J. BREDENKAMP. 1998. Classification of the natural vegetation of Mtendere Game Ranch in the Chibombo District of the Central Province, Zambia. Koedoe 41(2): 13-26.

CILLIERS, S.S., E. VAN WYK and G.J BREDENKAMP. 1999. Urban nature conservation: vegetation of natural areas in the Potchefstroom municipal area, North West Province, South Africa. Koedoe 42(1): 1-30.

DE KLERK, J., L.R. BROWN, H. BEZUIDENHOUT and G. CASTLEY. 2001. The estimation of herbage yields under fire and grazing treatments in the Mountain Zebra National Park. Koedoe 44(1): 9-15.

DUDLEY, C.O. 1997. The candelabra tree (Euphorbia ingens): a source of water for black rhinoceros in Liwonde National Park, Malawi. Koedoe 40(1): 57-62.

DU PLESSIS, W.P. 1997. Refinements to the burning strategy in the Etosha National Park, Namibia. Koedoe 40(1):63-76.

DU PLESSIS, W.P., G.J. BREDENKAMP and W.S.W. TROLLOPE. 1998a. Response of herbaceous species to a degradation gradient in the western region of Etosha National Park, Namibia. Koedoe 41(1): 9-18.

DU PLESSIS, W.P., G.J. BREDENKAMP and W.S.W. TROLLOPE. 1998b. Development of a technique for assessing veld condition in Etosha National Park, Namibia, using key herbaceous species. Koedoe 41(1): 19-30.

ECKHARDT, H.C., N. VAN ROOYEN and G.J. BREDENKAMP 1996. The plant communities and species richness of the Alepidea longifoliaMonocymbium ceresiiforme High-altitude Grassland of northern KwaZulu-Natal. Koedoe 39(2): 53-68.

ECKHARDT, H.C., N. VAN ROOYEN and G.J. BREDENKAMP. 1997. Plant communities of the 
forests, woodlandsand thickets in northern KwZulu-Natal. Koedoe 40(1): 91-112.

ENSLIN, B.W., A.L.F. POTGIETER, H.C. BIGGS and R. BIGGS. 2000. Long term effects of fire frequency and season on the woody vegetation dynamics of the Sclerocarya birrea/Acacia nigrescens savanna of the Kruger National Park. Koedoe 43(1): 27-37.

FOXCROFT, L.C. and J.H. HOFFMANN. 2000. Dispersal of Dactylopius opuntiae Cockerell (Homoptera: Dactylopiidae), a biological control agent of Opuntia stricta (Haworth.) Haworth. (Cactaceae) in the Kruger National Park. Koedoe 43(2): 1-5.

HISCOCKS, Kay. 1999. The impact of an increasing elephant population on the woody vegetation in southern Sabi Sand Wildtuin, South Africa. Koedoe 42(2): 47-55.

KEMP, A.C., K.S. BEGG, G.A. BENN and P. CHADWICK. 1997. A visual assessment of vegetation structure for the Kruger National Park. Koedoe 40(2): 117-121.

LANDMAN, M. and G.I.H. KERLEY. 2001. Dietary shifts: do grazers become browsers in the Thicket Biome? Koedoe 44(1): 31-36.

LOTTER, W.D. and J.H. HOFFMANN. 1998. An integrated management plan for the control of Opuntia stricta (cactaceae) in the Kruger National Park, South Africa. Koedoe 41(1): 63-68.

LOTTER, W.D., L. THATCHER, L. ROSSOUW and C.F. REINHARDT. 1999. The influence of baboon predation and time in water on germination and early establishment of Opuntia stricta (Australian pest pear) in the Kruger National Park. Koedoe 42(1): 43-50.

MATTHEWS, W.S. G.J. BREDENKAMP and N. VAN ROOYEN. 1994. The phytosociology and syntaxonomy of relatively low-altitude areas in the North-eastern Mountain Sourveld, in the eastern Transvaal escarpment region. Koedoe 37(2): 73-88.

PALEY, R.G.T. and G.I.H. KERLEY. 1998. The winter diet of elephant in Eastern Cape Subtropical Thicket, Addo Elephant National Park. Koedoe 41(1): 37-46.

PIENAAR, D. J., J. DU P. BOTHMA and G. K. THERON. 1993. Landscape preference of the white rhinoceros in the central and northern Kruger National Park. Koedoe 36(1): 79-86.

REINHARDT, C.F. 2000. Weed management practices in natural ecosystems: a critical overview. Koedoe 43(1): 67-74.

RÖSCH, HELGA. 2001. The identification and description of the management units of the Goegap Nature Reserve. Koedoe 44(1): 17-30.

RUBIN, FRANCINE and A.R. PALMER. 1996. The physical environment and major plant communities of the Karoo National Park, South Africa. Koedoe 39(2): 25-52.

SCHMIDT, A.G., G.K. THERON and W. VAN HOVEN. 1995. A comparison of some methods used to estimate the grazing capacity of a game ranch in Northern Province, South Africa. Koedoe 38(2): 123-128.

SCHOLES, R.J., N. GUREJA, M. GIANNECCHINNI, D. DOVIE, B. WILSON, N. DAVIDSON, K. PIGGOTT, C. MCLOUGHLIN, K. VAN DER VELDE, A FREEMAN, S. BRADLEY, R. SMART and S. NDALA. 2001. The environment and vegetation of the flux measurement site near Skukuza, Kruger National Park. Koedoe 44(1): 73-83.

SHACKLETON, C.M. and R.J. SCHOLES. 2000. Impact of fire frequency on woody community structure and soil nutrients in the Kruger National Park. Koedoe 43(1): 75-81.

SMIT, C.M., G.J. BREDENKAMP, N. VAN ROOYEN, A.E. VAN WYK and J.M. COMBRINCK. 1997. Vegetation of the Witbank Nature Reserve and its importance for conservation of threatened Rocky Highveld Grassland. Koedoe 40(2): 85-104.

STEYN, A. and M. STALMANS. 2001. Selective habitat utilisation and impact on vegetation by African elephant within a heterogeneous landscape. Koedoe 44(1): 95-103.

THRASH, I. 1998. Association of three succulent plant species with woody canopy in the mixed bushveld, South Africa. Koedoe 41(2): 95-101.

TROLLOPE, W.S.W. 1993. Fire regime of the Kruger National Park for the period 1980 - 1992. Koedoe 36(2): 45-52.

TROLLOPE, W.S.W., L.A. TROLLOPE, H.C. BIGGS, D. PIENAAR and A.L.F. POTGIETER. 1998. Long term changes in the woody vegetation of the Kruger National Park, with special ref erence to the effects of elephants and fire. Koedoe 41(2): 103-112.

VAN ROOYEN, N. and H. BEZUIDENHOUT. 1997. New records of flowering plants and ferns from the Kalahari Gemsbok National Park. Koedoe 40(2): 105-116.

VAN WILGEN, B.W., H.C. BIGGS and A.L.F. POTGIETER. 1998. Fire management and research in the Kruger National Park, with suggestions on the detection of thresholds of potential concern. Koedoe 41(1): 69-87.

VILJOEN, A.J. 1995. The influence of the 1991/92 drought on the woody vegetation of the Kruger National Park. Koedoe 38(2): 85-97.

VISSER, N., W. VAN HOVEN and G.K. THERON. 1996. The vegetation and identification of management units of the Honnet Nature Reserve, Northern Province, South Africa. Koedoe 39(1): 25-42.

WESSELS, DIRK and LUDGER KAPPEN. 1993. Photosynthetic performance of rock-colonising lichens in the Mountain Zebra National Park, South Africa. Koedoe 36(1): 27-48.

WESSELS, D., D. VENTER, W. WESSELS and L. WESSELS. 1995. Experimental strain analysis of Clarens Sandstone colonised by endolithic lichens. Koedoe 38(2): 35-47. 
WINKLER, A. and N. OWEN-SMITH. 1995. Habitat utilisation by Cape mountain zebras in the Mountain Zebra National Park. Koedoe 38(1): 83-93.

WRENCH, J.M., H.H. MEISSNER and C.C. GRANT. 1997. Assessing diet quality of African ungulates from faecal analyses: the effect of forage quality, intake and herbivore species. Koedoe 40(1): 125-136.

ZIETSMAN, P.C. and H. BEZUIDENHOUT. 1999. Flowering plant biodiversity of Augrabies Falls National Park: a comparison between Augrabies Falls National Park, Kalahari Gemsbok National Park, Vaalbos National Park and Goegap Nature Reserve. Koedoe 42(2): 95-112.

\section{Ecology and behaviour}

BHIMA, R. and C.O. DUDLEY. 1997. The influence of the Shire River on Liwonde National Park, Malawi, with special reference to elephant movements. Koedoe 40(2): 9-18.

DE KLERK, J., L.R. BROWN, H. BEZUIDENHOUT and G. CASTLEY. 2001. The estimation of herbage yields under fire and grazing treatments in the Mountain Zebra National Park. Koedoe 44(1): 9-15.

DU PLESSIS, W.P., G.J. BREDENKAMP and W.S.W. TROLLOPE. 1998a. Response of herbaceous species to a degradation gradient in the western region of Etosha National Park, Namibia. Koedoe 41(1): 9-18.

ENSLIN, B.W., A.L.F. POTGIETER, H.C. BIGGS and R. BIGGS. 2000. Long term effects of fire frequency and season on the woody vegetation dynamics of the Sclerocarya birrea/Acacia nigrescens savanna of the Kruger National Park. Koedoe 43(1): 27-37.

GRANT, C.C., H.H. MEISSNER and W.A. SCHULTHEISS. 1995. The nutritive value of veld as indicated by faecal phosphorous and nitrogen and its relation to the condition and movement of prominent ruminants during the 1992-1993 drought in the Kruger National Park. Koedoe 38(1):17-31.

MARX, H.M. and A. AVENANT-OLDEWAGE. 1998. A further investigation into the bioaccumulation of lead and zinc in the organs and tissues of the African sharptooth catfish, Clarias gariepinus from two localities in the Olifants River, Kruger National Park. Koedoe 41(2): 27-43.

MEYER, V.W., L.E.O. BRAACK and H.C. BIGGS. 2000. Distribution and density of Cubitermes Wasmann (Isoptera: Termitidae) mounds in the northern Kruger National Park. Koedoe 43(1): 57-65.

PIENAAR, D. J., J. DU P. BOTHMA and G. K. THERON. 1993. Landscape preference of the white rhinoceros in the central and northern Kruger National Park. Koedoe 36(1): 79-86.

RASA, O.A.E. 1994. Behavioural adaptations to moisture as an environmental constraint in a nocturnal burrow-inhabiting Kalahari detritivore Parastizopus armaticeps Peringuey (Coleoptera: Tenebrionidae). Koedoe 37(1): 57-66.

SHACKLETON, C.M. and R.J. SCHOLES. 2000. Impact of fire frequency on woody community structure and soil nutrients in the Kruger National Park. Koedoe 43(1): 75-81.

SLOTOW, R. and G. VAN DYK. 2001. Role of delinquent young "orphan" male elephants in high mortality of white rhinoceros in Pilanesberg National Park, South Africa. Koedoe 44(1): 85-94.

TROLLOPE, W.S.W. 1993. Fire regime of the Kruger National Park for the period 1980 - 1992. Koedoe 36(2): 45-52.

TROLLOPE, W.S.W., L.A. TROLLOPE, H.C. BIGGS, D. PIENAAR and A.L.F. POTGIETER. 1998. Long term changes in the woody vegetation of the Kruger National Park, with special ref erence to the effects of elephants and fire. Koedoe 41(2): 103-112.

VAN WILGEN, B.W., H.C. BIGGS and A.L.F. POTGIETER. 1998. Fire management and research in the Kruger National Park, with suggestions on the detection of thresholds of potential concern. Koedoe 41(1): 69-87.

VILJOEN, P.C. 1995. Changes in number and distribution of hippopotamus (Hippopotamus amphibius) in the Sabie River, Kruger National Park, during the 1992 drought. Koedoe 38(2): 115-121.

WATSON, L.H. 1999. Eland browsing of Grewia occidentalis in semi-arid shrubland: the influence of bush clumps. Koedoe 42(1): 79-84.

WINKLER, A. and N. OWEN-SMITH. 1995. Habitat utilisation by Cape mountain zebras in the Mountain Zebra National Park. Koedoe 38(1): 83-93.

\section{Wildlife conservation $\&$ techniques}

BANCROFT, C.M., H. BEZUIDENHOUT and J.G. NEL. 1998. Use of veld condition assessment to set objectives and targets for an ISO 14001 environmental management system for Vaalbos National Park. Koedoe 41(2): 1-12.

BEZUIDENHOUT, H., H.C. BIGGS and G.J. BREDENKAMP. 1996. A process supported by the utility BBPC for analysing Braun-Blanquet data on a personal computer. Koedoe 39(1): 107-112.

BIGGS, H.C. and A.L.F. POTGIETER. 1999. Overview of the fire management policy of the Kruger National Park. Koedoe 42(1): 101-110.

BOTHMA, J. DU P. and E.A.N. LE RICHE. 1993. Disturbance bias when tracking Kalahari leopards Panthera pardus by spoor. Koedoe 36(2): 109-112. 
BOTHMA, J. DU P., S. VAN HOVEN and E.A.N. LE RICHE. 1993. GPS-corrected and GIS-based remapping of the Kalahari Gemsbok National Park and the adjacent area in Botswana. Koedoe 36(2): 105-108.

BOTHMA J. du P., N. VAN ROOYEN and E.A.N. LE RICHE. 1997. Multivariate analysis of the hunting tactics of Kalahari leopards. Koedoe 40(1): 41-56.

BREDENKAMP, G.J. and H. BEZUIDENHOUT. 1995. A proposed procedure for the analysis of large phytosociological data sets in the classification of South African grasslands. Koedoe 38(1): 33-39.

BEZUIDENHOUT, H., H.C. BIGGS and G.J. BREDENKAMP. 1996. A process supported by the utility BBPC for analysing Braun-Blanquet data on a personal computer. Koedoe 39(1): 107-112.

BRITS, J, M.W. VAN ROOYEN and N. VAN ROOYEN. 2000. Technique to study the impact of large herbivores on woody vegetation within piospheres. Koedoe 43(2): 47-56.

CHAPPELL, C.A. and M.A. BROWN. 1993. The use of remote sensing in quantifying rates of soil erosion. Koedoe 36(1): 1-14.

DE KLERK, J., L.R. BROWN, H. BEZUIDENHOUT and G. CASTLEY. 2001. The estimation of herbage yields under fire and grazing treatments in the Mountain Zebra National Park. Koedoe 44(1): 9-15.

DU PLESSIS, W.P. 1997. Refinements to the burning strategy in the Etosha National Park, Namibia. Koedoe 40(1):63-76.

DU PLESSIS, W.P., G.J. BREDENKAMP and W.S.W. TROLLOPE. 1998b. Development of a technique for assessing veld condition in Etosha National Park, Namibia, using key herbaceous species. Koedoe 41(1): 19-30.

ELS, H. and J. DU P. BOTHMA. 2000. Developing partnerships in a paradigm shift to achieve conservation reality in South Africa. Koedoe 43(1): 19-26.

ENGLISH, R.A., M. STALMANS, M.G.L. MILLS and A. VAN WYK. 1993. Helicopter-assisted boma capture of African wild dogs Lycaon pictus. Koedoe 36(1): 103-106.

FOXCROFT, L.C. and J.H. HOFFMANN. 2000. Dispersal of Dactylopius opuntiae Cockerell (Homoptera: Dactylopiidae), a biological control agent of Opuntia stricta (Haworth.) Haworth. (Cactaceae) in the Kruger National Park. Koedoe 43(2): $1-5$.

GRANT, C.C. and J.L. VAN DER WALT. 2000. Towards an adaptive management approach for the conservation of rare antelope in the Kruger National Park-outcome of a workshop held in May 2000. Koedoe 43(2): 103-112.

HANEKOM, N., J.B. MANN-LANG, B.Q. MANN and T.V.Z. CARINUS. 1997. Shore-angling catches in the Tsitsikamma National Park, 19891995. Koedoe 40(2): 37-56.
KARCZMARSKI, L., V.G. COCKCROFT, A. MCLACHLAN and P.E.D. WINTER. 1998. Recommendations for the conservation and management of humpback dolphins Sousa chinensis in the Algoa Bay region, South Africa. Koedoe 41(2): 121-129.

LOTTER, W.D. and J.H. HOFFMANN. 1998. An integrated management plan for the control of Opuntia stricta (cactaceae) in the Kruger National Park, South Africa. Koedoe 41(1): 63-68.

NOVELLIE, P.A. 1994. Monitoring the condition of mountain zebra habitat in the Mountain Zebra National Park. Koedoe 37(1): 35-39.

NOVELLIE, P.A. and M. KNIGHT. 1994. Repatriation and translocation of ungulates into South African national parks: an assessment of past attempts. Koedoe 37(1): 115-119.

NOVELLIE, P. and A. WINKLER. 1993. A simple index of habitat suitability for Cape mountain zebras. Koedoe 36(2): 53-59.

NOVELLIE, P., H. BIGGS, L. BRAACK, N. HANEKOM, M. KNIGHT, M. MACGREGOR, R. RANDALL, I. RUSSELL and F. VENTER. 1999. Peripheral development: position paper for the Directorate of the South African National Parks. Koedoe 42(2): 113-116.

PARR, C.L. and B.H. BROCKETT. 1999. Patchmosaic burning: a new paradigm for savanna fire management in protected areas? Koedoe 42(2): $117-130$.

REILLY, B.K. and R.H. EMSLIE. 1998. Power and precision of replicated helicopter surveys in mixed bushveld. Koedoe 41(1): 47-56.

REINHARDT, C.F. 2000. Weed management practices in natural ecosystems: a critical overview. Koedoe 43(1): 67-74.

RÖSCH, HELGA. 2001. The identification and description of the management units of the Goegap Nature Reserve. Koedoe 44(1): 17-30.

SCHMIDT, A.G. and J.W. JORDAAN. 1999. An approach to assessing the financial viability of bush clearing on game ranches in savanna regions. Koedoe 42(2): 65-72.

SCHMIDT, A.G., G.K. THERON and W. VAN HOVEN. 1995. A comparison of some methods used to estimate the grazing capacity of a game ranch in Northern Province, South Africa. Koedoe 38(2): 123-128.

SOLOMON, M., N. ZAMBATIS, H.C. BIGGS and N. MARÉ. 1999. Comparison of classifications commonly used as templates for management, scientific and GIS work in the Kruger National Park. Koedoe 42(2): 131-142.

SWANEPOEL, D. G. J. 1996. Identification of the Nile crocodile Crocodylus niloticus by the use of natural tail marks. Koedoe 39(1): 113-116.

THRASH, I. and J.F. DERRY. 1999. The nature and modelling of piospheres: a review. Koedoe 42(2): 73-94.

TROLLOPE, W.S.W. 1993. Fire regime of the Kruger National Park for the period 1980 - 1992. Koedoe 36(2): 45-52. 
VAN WILGEN, B.W., H.C. BIGGS and A.L.F. POTGIETER. 1998. Fire management and research in the Kruger National Park, with suggestions on the detection of thresholds of potential concern. Koedoe 41(1): 69-87.

VILJOEN, P.C. and P.F. RETIEF. 1994. The use of the Global Positioning System for real-time data collecting during ecological aerial surveys in the Kruger National Park, South Africa. Koedoe 37(1): 149-157.

WEPENER, V, N. EULER, J.H.J. VAN VUREN, H.H. DU PREEZ and ASTRI KöHLER. 1992. The development of an aquatic toxicity index as a tool in the operational management of water quality in the Olifants River (Kruger National Park). Koedoe 35(2): 1-9.

WEPENER, V., J.H.J. VAN VUREN \& H.H. DU PREEZ. 1999. The implementation of an aquatic toxicity index as a water quality monitoring tool in the Olifants River (Kruger National Park). Koedoe 42(1): 85-96.

WHYTE, I.J., H.C. BIGGS, A. GAYLARD and L.E.O. BRAACK. 1999. A new policy for the management of the Kruger National Park's elephant population. Koedoe 42(1): 111-132.

WOODD, A.M. 1999. A demographic model to predict future growth of the Addo elephant population. Koedoe 42(1): 79-100.

WRENCH, J.M., H.H. MEISSNER, C.C. GRANT and N.H. CASEY. 1996. Environmental factors that affect the concentration of $\mathrm{P}$ and $\mathrm{N}$ in faecal samples collected for the determination of nutritional status. Koedoe 39(2): 1-6.

WRENCH, J.M., H.H. MEISSNER and C.C. GRANT. 1997. Assessing diet quality of African ungulates from faecal analyses: the effect of forage quality, intake and herbivore species. Koedoe 40(1): 125-136.

\section{Zoology:}

\section{Invertebrata}

AVENANT-OLDEWAGE, ANNEMARIÉ. 1994. A new species of Argulus from Lake Kosi Bay, South Africa and distribution records of the genus. Koedoe 37(2): 89-96.

AVENANT-OLDEWAGE, ANNEMARIé and ELMINE KNIGHT. 1994. A diagnostic species compendium of the genus Chonopeltis Thiele, 1900 (Crustacea: Branchiura) with notes on its geographical distribution. Koedoe 37(1): 41-56.

BOTHA, ANNELIZE and J. HEYNS. 1992. Further records and descriptions of nematodes from rivers in the Kruger National Park (orders Enoplida, Chromadorida, Monhysterida, Mononchida and Araeolaimida). Koedoe 35(2): 11-25.

BOTHA, ANNELIZE and J. HEYNS. 1993a. New records of Tylenchida, Araeolaimida and Enopli- da from the Kruger National Park, with an addendum to the check list of nematode species in the park. Koedoe 36(1): 61-65.

BOTHA, ANNELIZE and J. HEYNS. 1993b. Species of the genera Oxydirus, Dorylaimellus (Axodorylaimellus), Laimydorus and Rhabdolaimus from rivers in the Kruger National Park (Nematoda: Dorylaimida and Araeolaimida). Koedoe 36(1): 49-60.

BRAACK, L.E.O. 1995. Seasonal activity of savanna termites during and after severe drought. Koedoe 38(1): 73-82.

DE KOCK, K.N. and C.T. WOLMARANS. 1998. A re-evaluation of the occurrence of freshwater molluscs in the Kruger National Park. Koedoe 41(1): $1-8$

DIPPENAAR-SCHOEMAN, ANNA S., ASTRI LEROY, MARIE DE JAGER and ANNETTE VAN DEN BERG. 1999. A check list of the spider fauna of the Karoo National Park, South Africa (Arachnida: Araneae). Koedoe 42(1): 3142.

DIPPENAAR-SCHOEMAN, A.S. and M.S. HARVEY. 2000. A check list of the pseudoscorpions of South Africa (Arachnida: Pseudoscorpiones). Koedoe 43(2): 89-102.

FITZPATRICK, M.J. 1994. Range extension of Ceratogyrus sanderi Strand, 1906 (Araneae: Theraphosidae). Koedoe 37(1): 121-122.

FOXCROFT, L.C. and J.H. HOFFMANN. 2000. Dispersal of Dactylopius opuntiae Cockerell (Homoptera: Dactylopiidae), a biological control agent of Opuntia stricta (Haworth.) Haworth. (Cactaceae) in the Kruger National Park. Koedoe 43(2): 1-5.

HEYNS, J. 1994. Description of Longidoroides wiesae spec. nov. from the Kruger National Park (Nematoda: Dorylaimida). Koedoe 37(2): 97 104.

HEYNS, J. 2000. The genus Discolaimus in Southern Africa. I. Introduction and redescription of $D$. krugeri Furstenberg \& Heyns, 1966 (Nematoda: Dorylaimida). Koedoe 43(2): 7-15.

HEYNS, J. and ANTOINETTE SWART. 1998. Longidorus jagerae sp.n., another longidorid species with globular inclusions in the prerectum (Nematoda: Longidoridae). Koedoe 41(1): 31-36.

HORAK, I.G., V. DE VOS and L.E.O. BRAACK. 1995. Arthropod burdens of impalas in the Skukuza region during two droughts in the Kruger National Park. 1995. Koedoe 38(1): 65 71.

LUUS-POWELL, WILMIEN and ANNEMARIÉ AVENANT-OLDEWAGE. 1996. Surface morphology of Chonopeltis victori Avenant-Oldewage, 1991, and aspects of the histomorphology. Koedoe 39(1): 55-70.

MEYER, V.W., L.E.O. BRAACK and H.C. BIGGS. 2000. Distribution and density of Cubitermes Wasmann (Isoptera: Termitidae) mounds in the 
northern Kruger National Park. Koedoe 43(1): 57-65.

OLIVIER, P.A.S. and J.P. VAN NIEKERK. 1995. New morphological information on the parasitic copepod Lernanthropus sarbae Kensley \& Grindley, 1973 (Copepoda: Lernanthropidae) from Lake St. Lucia, South Africa, using scanning electron microscopy. Koedoe 38(2): 99-104.

OLIVIER, P.A.S. and P.D. THERON. 1997. The genus Eupodes Koch, 1835 (Acari: Prostigmata: Eupodidae) from southern African soil and vegetation. Part 1. Characterisation of the genus, designation of the type species and descriptions of three new species. Koedoe 40(2): 57-73.

RASA, O.A.E. 1994. Behavioural adaptations to moisture as an environmental constraint in a nocturnal burrow-inhabiting Kalahari detritivore Parastizopus armaticeps Peringuey (Coleoptera: Tenebrionidae). Koedoe 37(1): 57-66.

SAMWAYS, M.J., R. OSBORN and I. VAN HEERDEN. 1996. Distribution of benthic invertebrates at different depths in a shallow reservoir in the KwaZulu-Natal Midlands. Koedoe 39(2): 69-76.

SPICKETT, A.M., I.G. HORAK, HELOISE HEYNE and L.E.O. BRAACK. 1995. The effect of severe drought on the abundance of ticks on vegetation and on scrub hares in the Kruger National Park. 1995. Koedoe 38(1): 59-64.

VAN DEN BERG, ESTHER. 1993. A first list of plant-parasitic nematodes from the Wilderness National Park, with a description of Ogma sekgwaum spec. nov. Koedoe 36(2): 61-76.

VAN DEN BERG, ESTHER. 1996. A first list of plant-parasitic nematodes from the Tsitsikamma National Park, with descriptions of two new species of the subfamily Criconematinae. Koedoe 39(1): 43-54.

VAN DEN BERG, A. and A.S. DIPPENAARSCHOEMAN, 1994. A revision of the Afrotropical species of the genus Tibellus Simon (Araneae: Philodromidae). Koedoe 37(1): 67-114

\section{Pisces}

AVENANT-OLDEWAGE, ANNEMARIÉ and HAZEL MARX. 2000. Manganese, nickel and strontium bioaccumulation in the tissues of the African sharptooth catfish, Clarias gariepinus from the Olifants River, Kruger National Park. Koedoe 43(2): 17-33.

BUERMANN, Y., H.H. DU PREEZ, G.J. STEYN, J.T. HARMSE and A. DEACON. 1995. Suspended silt concentrations in the lower Olifants River (Mpumalanga) and the impact of silt releases from the Phalaborwa Barrage on water quality and fish survival. Koedoe 38(2): 11-34.

DU PREEZ, H.H., M. VAN DER MERWE and J.H.J. VAN VUREN. 1997. Bio-accumulation of selected metals in African sharptooth catfish Clarias gariepinus from the lower Olifants River,
Mpumalanga, South Africa. Koedoe 40(1): $77-$ 90.

GAGIANO, C.L., G.J. STEYN and H.H. DU PREEZ. 1996. Tooth replacement of tigerfish Hydrocynus vittatus from the Kruger National Park. Koedoe 39(1): 117-122.

HANEKOM, N., J.B. MANN-LANG, B.Q. MANN and T.V.Z. CARINUS. 1997. Shore-angling catches in the Tsitsikamma National Park, 19891995. Koedoe 40(2): 37-56.

MANN, B.Q. and C.D. BUXTON. 1992. Diets of Diplodus sargus capensis and D. cervinus hottentotus (Pisces: Sparidae) on the Tsitsikamma coast, South Africa. Koedoe 35(2): 27-36.

MARX, H.M. and A. AVENANT-OLDEWAGE. 1998. A further investigation into the bioaccumulation of lead and zinc in the organs and tissues of the African sharptooth catfish, Clarias gariepinus from two localities in the Olifants River, Kruger National Park. Koedoe 41(2): 27-43.

RUSSELL, I.A. 1997. Spatial variation in the structure of fish assemblages in the Vaalbos National Park. Koedoe 40(1): 113-123.

RUSSELL, I.A. 1999b. Freshwater fish of the Wilderness National Park. Koedoe 42(1): 73-78.

SMIT, L., H.H. DU PREEZ and G.J. STEYN. 1998. Influence of natural silt on the survival of Oreochromis mossambicus yolk sac larvae. Koedoe 41(1): 57-62.

VAN DER MERWE, MARINDA, J.H.J. VAN VUREN and H.H. DU PREEZ. 1993. Lethal copper concentration levels for Clarias gariepinus (Burchell, 1822) a preliminary study. Koedoe 36(2): 77-86.

VAN DER WAAL, B.C.W. 1998. Survival strategies of sharptooth catfish Clarias gariepinus in desiccating pans in the northern Kruger National Park. Koedoe 41(2): 131-138.

WOOD, A.D., S.L. BROUWER, P.D. COWLEY and T.D. HARRISON. 2000. An updated check list of the ichthyofaunal species assemblage of the Tsitsikamma National Park, South Africa. Koedoe 43(1): 83-95.

\section{Amphibia}

VAN DIJK, D.E. 1996. Anuran fauna of the Lesotho Highlands in the Khatse Dam catchment area and Jorodane River region. Koedoe 39(2): 77-90.

\section{Reptilia}

BRANCH, W.R. and G.V. HAAGNER. 1992. New reptile records from three southern national parks. Koedoe 35(2): 59-60.

CORDES, I.G. and P. LE F.N. MOUTON. 1996. The conservation status of the Saldanha-Langebaan lizard fauna. Koedoe 39(1): 71-84.

MOUTON, P. LE F.N. and J.H. VAN WYK. 1993. Reptile fauna of the Katse Dam catchment area 
and a biogeographical assessment of species composition in the Lesotho Highlands. Koedoe 36(1): 67-78.

SWANEPOEL, D. G. J. 1996. Identification of the Nile crocodile Crocodylus niloticus by the use of natural tail marks. Koedoe 39(1): 113-116.

SWANEPOEL, D.G.J., N.S. FERGUSON and M.R. PERRIN. 2000. Nesting ecology of Nile crocodiles (Crocodylus niloticus) in the Olifants River, Kruger National Park. Koedoe 43(2): 35-46.

\section{Aves}

DE SWARDT, D.H. and D.J. VAN NIEKERK. 1996. An annotated check list of the birds of Qwaqwa National Park. Koedoe 39(1): 89-106.

\section{Mammalia}

ACKERMAN, D.J., A.J. REINECKE and H.J. ELS. 1996a. A scanning electron microscopic study of impala (Aepyceros melampus) sperm from the Kruger National Park. Koedoe 39(2): 91-104.

ACKERMAN, D.J., A.J. REINECKE and H.J. ELS. 1996b. Transmission electron microscopic study of impala (Aepyceros melampus) sperm from the Kruger National Park. Koedoe 39(2): 105-120.

ACKERMAN, D.J., A.J. REINECKE and H.J. ELS. 1997a. Transmission electron microscopic observations of flagellum abnormalities in impala (Aepyceros melampus) sperm from the Kruger National Park. Koedoe 40(1): 1-13.

ACKERMAN, D.J., A.J. REINECKE and H.J. ELS. 1997b. Transmission electron microscopic observations of acrosome and head abnormalities in impala (Aepyceros melampus) sperm from the Kruger National Park. Koedoe 40(1):15-30

ANDERSON, M.D. and J.H. KOEN. 1993. Body measurements of mountain reedbuck Redunca fulvorufula fulvorufula from Rolfontein Nature Reserve, South Africa. Koedoe 36(1): 99-101.

AVENANT, N.L. 1997. Mammals recorded in the QwaQwa National Park (1994-1995). Koedoe 40(1): 31-40.

BHIMA, R. and J. DU P. BOTHMA. 1997. Age structure of elephants in Liwonde National Park, Malawi. Koedoe 40(2): 1-8.

BHIMA, R. and C.O. DUDLEY. 1997. The influence of the Shire River on Liwonde National Park, Malawi, with special reference to elephant movements. Koedoe 40(2): 9-18.

BOTHMA, J. DU P. and E.A.N. LE RICHE. 1993. Disturbance bias when tracking Kalahari leopards Panthera pardus by spoor. Koedoe 36(2): 109-112.

BOTHMA J. du P. and E.A.N. LE RICHE. 1994. Range use by an adult male caracal in the southern Kalahari. Koedoe 37(2): 105-108.

BOTHMA J. du P., N. VAN ROOYEN and E.A.N. LE RICHE. 1997. Multivariate analysis of the hunting tactics of Kalahari leopards. Koedoe 40(1): 41-56.

BRONNER, G.N. 1992. Notes on the early postnatal development of a giant golden mole Chrysospalax trevelyani (Günther, 1875) born in captivity (Mammalia: Insectivora; Chrysochloridae). Koedoe 35(2): 57-58.

DUDLEY, C.O. 1997. The candelabra tree (Euphorbia ingens): a source of water for black rhinoceros in Liwonde National Park, Malawi. Koedoe 40(1): 57-62.

ELS, L.M. and G.I.H. KERLEY. 1996. Biotic and abiotic correlates of small mammal community structure in the Groendal Wilderness Area, Eastern Cape, South Africa. Koedoe 39(2): 121.

ENGLISH, R.A., M. STALMANS, M.G.L. MILLS and A. VAN WYK. 1993. Helicopter-assisted boma capture of African wild dogs Lycaon pictus. Koedoe 36(1): 103-106.

ESSOP, M.F., A.J. HALL-MARTIN and E.H. HARLEY. 1996. Mitochondrial DNA analysis of two southern African elephant populations. Koedoe 39(1): 85-88.

FENTON, M. BROCK.1992. Pelage patterns and crypsis in roosting bats: Taphozous mauritianus and Epomophorus species. Koedoe 35(2): 49-55.

GRANT, C.C. and J.L. VAN DER WALT. 2000. Towards an adaptive management approach for the conservation of rare antelope in the Kruger National Park-outcome of a workshop held in May 2000. Koedoe 43(2): 103-112.

GRUBB, P. 1999. Types and type localities of ungulates named from southern Africa. Koedoe 42(2): $13-45$.

HISCOCKS, Kay. 1999. The impact of an increasing elephant population on the woody vegetation in southern Sabi Sand Wildtuin, South Africa. Koedoe 42(2): 47-55.

KARCZMARSKI, L., V.G. COCKCROFT, A. MCLACHLAN and P.E.D. WINTER. 1998. Recommendations for the conservation and management of humpback dolphins Sousa chinensis in the Algoa Bay region, South Africa. Koedoe 41(2): 121-129.

KUNTZSCH, V. and J.A.J. NEL. 1992. Diet of bateared foxes Otocyon megalotis in the Karoo. Koedoe 35(2): 37-48.

KYLE, R. 2000. Some notes on the occurrence and conservation status of Manis temminckii, the pangolin, in Maputaland, Kwazulu/Natal. Koedoe 43(1): 97-100.

LANDMAN, M. and G.I.H. KERLEY. 2001. Dietary shifts: do grazers become browsers in the Thicket Biome? Koedoe 44(1): 31-36.

LOTTER, W.D., L. THATCHER, L. ROSSOUW and C.F. REINHARDT. 1999. The influence of baboon predation and time in water on germination and early establishment of Opuntia stricta (Australian pest pear) in the Kruger National Park. Koedoe 42(1): 43-50.

MILLS, M.G.I. 1995. Notes on wild dog Lycaon pictus and lion Panthera leo population trends dur- 
ing a drought in the Kruger National Park. Koedoe 38(1): 95-99.

MONADJEM, A. 1998. Distributional patterns and conservation status of mammals of Swaziland, southern Africa. Koedoe 41(2): 45-59.

NEWBERY, CHRISTIA H. 1999. A key to the Soricidae, Macroscelididae, Gliridae and Muridae of Gauteng, North West Province, Mpumalanga and the Northern Province, South Africa. Koedoe 42(1): 51-55.

NOVELLIE, P.A. 1994. Monitoring the condition of mountain zebra habitat in the Mountain Zebra National Park. Koedoe 37(1): 35-39.

NOVELLIE, P.A. and M. KNIGHT. 1994. Repatriation and translocation of ungulates into South African national parks: an assessment of past attempts. Koedoe 37(1): 115-119.

NOVELLIE, P. and A. WINKLER. 1993. A simple index of habitat suitability for Cape mountain zebras. Koedoe 36(2): 53-59.

PALEY, R.G.T. and G.I.H. KERLEY. 1998. The winter diet of elephant in Eastern Cape Subtropical Thicket, Addo Elephant National Park. Koedoe 41(1): 37-46.

PENZHORN, B.L. and N.J. VAN DER MERWE. 1993. Testis size and spermatogenesis of tsessebes from Nylsvley Nature Reserve, Transvaal. Koedoe 36(1): 95-98.

PIENAAR, D. J., J. DU P. BOTHMA and G. K. THERON. 1993. Landscape preference of the white rhinoceros in the central and northern Kruger National Park. Koedoe 36(1): 79-86.

PRETORIUS, QUARTA, B.P. PRETORIUS and C.S. DANNHAUSER. 1996. The reproductive behaviour of the suni Neotragus moschatus zuluensis in captivity. Koedoe 39(1): 123-126.

RASMUSSEN, G.S.A. 1996. Predation on bat-eared foxes Otocyon megalotis by Cape hunting dogs Lycaon pictus. Koedoe 39(1): 127-134.

RAUBENHEIMER, E.J. 1999. Morphological aspect and composition of African elephant (Loxodonta africana) ivory. Koedoe 42(2): 57-64.

RAUBENHEIMER, E.J. 2000. Development of the tush and tusk and tusklessness in the African elephant (Loxodonta africana). Koedoe 43(2): $57-64$.

RAUTENBACH, I.L., G.N. BRONNER, and D.A. SCHLITTER. 1993. Karyotypic data and attendant systematic implications for the bats of southern Africa. Koedoe 36(2): 87-104.

SLOTOW, R. and G. VAN DYK. 2001. Role of delinquent young "orphan" male elephants in high mortality of white rhinoceros in Pilanesberg National Park, South Africa. Koedoe 44(1): 85-94.

SPICKETT, A.M., I.G. HORAK, HELOISE HEYNE and L.E.O. BRAACK. 1995. The effect of severe drought on the abundance of ticks on vegetation and on scrub hares in the Kruger National Park. 1995. Koedoe 38(1): 59-64.
STEYN, A. and M. STALMANS. 2001. Selective habitat utilisation and impact on vegetation by African elephant within a heterogeneous landscape. Koedoe 44(1): 95-103.

THRASH, I., G.K. THERON and J. DU P. BOTHMA. 1993. Herbivore dung deposit counts around drinking troughs in the Kruger National Park. Koedoe 36(1): 87-94.

TROLLOPE, W.S.W., L.A. TROLLOPE, H.C. BIGGS, D. PIENAAR and A.L.F. POTGIETER. 1998. Long term changes in the woody vegetation of the Kruger National Park, with special ref erence to the effects of elephants and fire. Koedoe 41(2): 103-112.

VILJOEN, P.C. 1995. Changes in number and distribution of hippopotamus (Hippopotamus amphibius) in the Sabie River, Kruger National Park, during the 1992 drought. Koedoe 38(2): 115-121.

VRAHIMIS, S. and O.B. KOK. 1994. Notes on the diurnal activity of early post-natal black wildebeest calves. Koedoe 37(2): 109-113.

WATSON, L.H. 1999. Eland browsing of Grewia occidentalis in semi-arid shrubland: the influence of bush clumps. Koedoe 42(1): 79-84.

WHYTE, I.J., H.C. BIGGS, A. GAYLARD and L.E.O. BRAACK. 1999. A new policy for the management of the Kruger National Park's elephant population. Koedoe 42(1): 111-132.

WINKLER, A. and N. OWEN-SMITH. 1995. Habitat utilisation by Cape mountain zebras in the Mountain Zebra National Park. Koedoe 38(1): 83-93.

WOODD, A.M. 1999. A demographic model to predict future growth of the Addo elephant population. Koedoe 42(1): 79-100.

WRENCH, J.M., H.H. MEISSNER and C.C. GRANT. 1997. Assessing diet quality of African ungulates from faecal analyses: the effect of forage quality, intake and herbivore species. Koedoe 40(1): $125-136$.

\section{Archaeology and History}

CARRUTHERS, JANE. 1993. 'Police boys' and poachers: Africans, wildlife protection and national parks, the Transvaal 1902 to 1950 . Koedoe 36(2): 11-22.

HOFFMAN, M.T. 1993. Major P.J. Pretorius and the decimation of the Addo elephant herd in 19191920: important reassessments. Koedoe 36(2): 23-44.

MWIMA, H.K. 2001. A brief history of Kafue National Park, Zambia. Koedoe 44(1): 57-72.

PLUG, I. 1993. The macrofaunal remains of wild animals from Abbot's Cave and Lame Sheep Shelter, Seacow Valley, Cape. Koedoe 36(1): 1526.

WEBLEY, LITA, FIONA ARCHER and J. BRINK. 1993. Die Toon: a Late Holocene site in the 
Richtersveld National Park, northern Cape. Koedoe 36(2): 1-9.

WINKLER, A. and N. OWEN-SMITH. 1995. Habitat utilisation by Cape mountain zebras in the Mountain Zebra National Park. Koedoe 38(1): 83-93.

\section{Bibliography}

Koedoe Supplement 1994

\section{Climate}

BRAACK, L.E.O. 1995. Seasonal activity of savanna termites during and after severe drought. Koedoe 38(1): 73-82.

GRANT, C.C., H.H. MEISSNER and W.A. SCHULTHEISS. 1995. The nutritive value of veld as indicated by faecal phosphorous and nitrogen and its relation to the condition and movement of prominent ruminants during the 1992-1993 crought in the Kruger National Park. Koedoe 38(1):17-31.

HERITAGE, G.L. and A.W. VAN NIEKERK. 1995. Drought conditions and sediment transport in the Sabie Rivier. Koedoe 38(2): 1-9.

HORAK, I.G., V. DE VOS and L.E.O. BRAACK. 1995. Arthropod burdens of impalas in the Skukuza region during two droughts in the Kruger National Park. 1995. Koedoe 38(1): 6571.

MILLS, M.G.I. 1995. Notes on wild dog Lycaon pictus and lion Panthera leo population trends during a drought in the Kruger National Park. Koedoe 38(1): 95-99.

SPICKETT, A.M., I.G. HORAK, HELOISE HEYNE and L.E.O. BRAACK. 1995. The effect of severe drought on the abundance of ticks on vegetation and on scrub hares in the Kruger National Park. 1995. Koedoe 38(1): 59-64.

VAN VOLLENHOVEN, ANTON C., ANTON J. PELSER \& JAN W. VAN DEN BOS. 1998. A historical-archaeological investigation of an Anglo-Boer War British outpost in the Kruger National Park. Koedoe 41(2): 113-120.

VILJOEN, A.J. 1995. The influence of the 1991/92 drought on the woody vegetation of the Kruger National Park. Koedoe 38(2): 85-97.

VILJOEN, P.C. 1995. Changes in number and distribution of hippopotamus (Hippopotamus amphibius) in the Sabie River, Kruger National Park, during the 1992 drought. Koedoe 38(2): 115-121.

ZAMBATIS, N and H.C. BIGGS. 1995. Rainfall and temperatures during the 1991/92 drought in the Kruger National Park. Koedoe 38(1): 1-16.

\section{Geology and Pedology}

BREDENKAMP, G.J. and M.S. DEUTSCHLÄNDER. 1994. The Themedo triandrae - Setarietum incrassatae, a new association from gabbro in the Manyeleti Game Reserve, Gazankulu, South Africa. Koedoe 37(2): 45-58.

BUERMANN, Y., H.H. DU PREEZ, G.J. STEYN, J.T. HARMSE and A. DEACON. 1995. Suspended silt concentrations in the lower Olifants River (Mpumalanga) and the impact of silt releases from the Phalaborwa Barrage on water quality and fish survival. Koedoe 38(2): 11-34.

CHAPPELL, C.A. and M.A. BROWN. 1993. The use of remote sensing in quantifying rates of soil erosion. Koedoe 36(1): 1-14.

HERITAGE, G.L. and A.W. VAN NIEKERK. 1995. Drought conditions and sediment transport in the Sabie Rivier. Koedoe 38(2): 1-9.

HERITAGE, G.L. and B.P. MOON. 2000. The contemporary geomorphology of the Sabie River in the Kruger National Park. Koedoe 43(1): 39-55.

PLUG, C. and I. PLUG. 1997. Popups on Moon Rock, Augrabies Falls National Park. Koedoe 40(2): 75-84.

RUBIN, FRANCINE and A.R. PALMER. 1996. The physical environment and major plant communities of the Karoo National Park, South Africa. Koedoe 39(2): 25-52.

SEYMORE, T., H.H. DU PREEZ, J.H.J. VAN VUREN, A. DEACON and G. STRYDOM. 1994. Variations in selected water quality variables and metal concentrations in the sediment of the lower Olifants and Selati rivers, South Africa. Koedoe 37(2): 1-18.

SHACKLETON, C.M. and R.J. SCHOLES. 2000. Impact of fire frequency on woody community structure and soil nutrients in the Kruger National Park. Koedoe 43(1): 75-81.

SMIT, L., H.H. DU PREEZ and G.J. STEYN. 1998. Influence of natural silt on the survival of Oreochromis mossambicus yolk sac larvae. Koedoe 41(1): 57-62.

WESSELS, D., D. VENTER, W. WESSELS and L. WESSELS. 1995. Experimental strain analysis of Clarens Sandstone colonised by endolithic lichens. Koedoe 38(2): 35-47.

\section{Environmental impact on rivers \& water quality}

AVENANT-OLDEWAGE, ANNEMARIÉ and HAZEL MARX. 2000. Manganese, nickel and strontium bioaccumulation in the tissues of the African sharptooth catfish, Clarias gariepinus from the Olifants River, Kruger National Park. Koedoe 43(2): 17-33.

BUERMANN, Y., H.H. DU PREEZ, G.J. STEYN, J.T. HARMSE and A. DEACON. 1995. Suspended silt concentrations in the lower Olifants River 
(Mpumalanga) and the impact of silt releases from the Phalaborwa Barrage on water quality and fish survival. Koedoe 38(2): 11-34.

DU PREEZ, H.H., M. VAN DER MERWE and J.H.J. VAN VUREN. 1997. Bio-accumulation of selected metals in African sharptooth catfish Clarias gariepinus from the lower Olifants River, Mpumalanga, South Africa. Koedoe 40(1): 77 90.

HERITAGE, G.L. and A.W. VAN NIEKERK. 1995. Drought conditions and sediment transport in the Sabie Rivier. Koedoe 38(2): 1-9.

HERITAGE, G.L., B.P. MOON, G.P. JEWITT, A.R.G. LARGE and M. ROUNTREE. 2001. The February 2000 floods on the Sabie River, South Africa: an examination of their magnitude and frequency. Koedoe 44(1):37-44.

MARX, H.M. and A. AVENANT-OLDEWAGE. 1998. A further investigation into the bioaccumulation of lead and zinc in the organs and tissues of the African sharptooth catfish, Clarias gariepinus from two localities in the Olifants River, Kruger National Park. Koedoe 41(2): 27-43.

MOON, B.P. and G.L. HERITAGE. 2001. The contemporary geomorphology of the Letaba River in the Kruger National Park. Koedoe 44(1): 45-55.

RUSSELL, I.A. 1996. Water quality in the Knysna estuary. Koedoe 39(1): 1-8.

RUSSELL, I.A. 1999a. Changes in the water quality of the Wilderness and Swartvlei lake systems, South Africa. Koedoe 42(1): 57-72.

SEYMORE, T., H.H. DU PREEZ, J.H.J. VAN VUREN, A. DEACON and G. STRYDOM. 1994. Variations in selected water quality variables and metal concentrations in the sediment of the lower Olifants and Selati rivers, South Africa. Koedoe 37(2): 1-18.

SCHOLES, R.J., N. GUREJA, M. GIANNECCHINNI, D. DOVIE, B. WILSON, N. DAVIDSON, K. PIGGOTT, C. MCLOUGHLIN, K. VAN DER VELDE, A FREEMAN, S. BRADLEY, R. SMART and S. NDALA. 2001. The environment and vegetation of the flux measurement site near Skukuza, Kruger National Park. Koedoe 44(1): 73-83.

VAN DER MERWE, MARINDA, J.H.J. VAN VUREN and H.H. DU PREEZ. 1993. Lethal copper concentration levels for Clarias gariepinus (Burchell, 1822) a preliminary study. Koedoe 36(2): 77-86.

WEPENER, V, N. EULER, J.H.J. VAN VUREN, H.H. DU PREEZand ASTRI KÖHLER. 1992.

The development of an aquatic toxicity index as a tool in the operational management of water quality in the Olifants River (Kruger National Park). Koedoe 35(2): 1-9.

WEPENER, V., J.H.J. VAN VUREN \& H.H. DU PREEZ. 1999. The implementation of an aquatic toxicity index as a water quality monitoring tool in the Olifants River (Kruger National Park). Koedoe 42(1): 85-96.

\section{Check list}

AVENANT, N.L. Mammals recorded in the QwaQwa National Park (1994-1995). Koedoe 40(1): 31-40.

DE SWARDT, D.H. and D.J. VAN NIEKERK. 1996. An annotated check list of the birds of Qwaqwa National Park. Koedoe 39(1): 89-106.

DIPPENAAR-SCHOEMAN, ANNA S., ASTRI LEROY, MARIE DE JAGER and ANNETTE VAN DEN BERG. 1999. A check list of the spider fauna of the Karoo National Park, South Africa (Arachnida: Araneae). Koedoe 42(1): 31-42.

DIPPENAAR-SCHOEMAN, A.S. and M.S. HARVEY. 2000. A check list of the pseudoscorpions of South Africa (Arachnida: Pseudoscorpiones). Koedoe 43(2): 89-102.

VAN ROOYEN, N. and H. BEZUIDENHOUT. 1997. New records of flowering plants and ferns from the Kalahari Gemsbok National Park. Koedoe 40(2): 105-116.

WEPENER, V, N. EULER, J.H.J. VAN VUREN, H.H. DU PREEZ and ASTRI KöHLER. 1992. The development of an aquatic toxicity index as a tool in the operational management of water quality in the Olifants River (Kruger National Park). Koedoe 35(2): 1-9.

WOOD, A.D., S.L. BROUWER, P.D. COWLEY and T.D. HARRISON. 2000. An updated check list of the ichthyofaunal species assemblage of the Tsitsikamma National Park, South Africa. Koedoe 43(1): 83-95.

\section{Issues in conservation}

ELS, H. and J. DU P. BOTHMA. 2000. Developing partnerships in a paradigm shift to achieve conservation reality in South Africa. Koedoe 43(1): 19-26.

KARCZMARSKI, L., V.G. COCKCROFT, A. MCLACHLAN and P.E.D. WINTER. 1998. Recommendations for the conservation and management of humpback dolphins Sousa chinensis in the Algoa Bay region, South Africa. Koedoe 41(2): 121-129.

LOTTER, W.D. and J.H. HOFFMANN. 1998. An integrated management plan for the control of Opuntia stricta (cactaceae) in the Kruger National Park, South Africa. Koedoe 41(1): 63-68.

SONNEKUS, I.P. and G.J. BREYTENBACH. 2000.

Technology for alignment of participants in 
nature conservation: a case study at the Southern African Wildlife College. Koedoe 43(2): 65-88.

SONNEKUS, I.P. and G.J. BREYTENBACH. 2001a. Conservation business: sustaining Africa's future. Koedoe 44(1): 105-124.

VAN WILGEN, B.W., H.C. BIGGS and A.L.F. POTGIETER. 1998. Fire management and research in the Kruger National Park, with suggestions on the detection of thresholds of potential concern. Koedoe 41(1): 69-87.

\section{Maps}

BOTHMA, J. DU P., S. VAN HOVEN and E.A.N. LE RICHE. 1993. GPS-corrected and GIS-based remapping of the Kalahari Gemsbok National Park and the adjacent area in Botswana. Koedoe 36(2): 105-108.

\section{Social Science}

ELS, H. and J. DU P. BOTHMA. 2000. Developing partnerships in a paradigm shift to achieve conservation reality in South Africa. Koedoe 43(1): 19-26.

\section{Parks (vol 35/2 - 44/1)}

\section{Addo Elephant National Park}

HOFFMAN, M.T. 1993. Major P.J. Pretorius and the decimation of the Addo elephant herd in 19191920: important reassessments. Koedoe 36(2): 23-44.

PALEY, R.G.T. and G.I.H. KERLEY. 1998. The winter diet of elephant in Eastern Cape Subtropical Thicket, Addo Elephant National Park. Koedoe 41(1): 37-46.

PLUG, C. and I. PLUG. 1997. Popups on Moon Rock, Augrabies Falls National Park. Koedoe 40(2): 75-84.

WOODD, A.M. 1999. A demographic model to predict future growth of the Addo elephant population. Koedoe 42(1): 79-100.

WRENCH, J.M., H.H. MEISSNER, C.C. GRANT and N.H. CASEY. 1996. Environmental factors that affect the concentration of $\mathrm{P}$ and $\mathrm{N}$ in faecal samples collected for the determination of nutritional status. Koedoe 39(2): 1-6.
ENGELBRECHT, W.G. and P.T. VAN DER WALT. 1993. Notes on the economic use of the Kruger National Park. Koedoe 36(2): 113-119.

FOURIE, J. 1994. Comments on national parks and future relations with neighbouring communities. Koedoe 37(1): 123-136.

LOADER, J.A. 1994. National Parks and social involvement - an argument. Koedoe 37(1): 137148.

MOLL, EUGENE. 2001. Comments on the article Technology for alignment of participants in nature conservation: a case study at the Southern African Wildlife College by I.P. Sonnekus and G.J. Breytenbach-Koedoe 43/2 (2000). Koedoe 44(1): 125-127.

SONNEKUS, I.P. and G.J. BREYTENBACH. 2000. Technology for alignment of participants in nature conservation: a case study at the Southern African Wildlife College. Koedoe 43(2): 65-88.

SONNEKUS, I.P. and G.J. BREYTENBACH. 2001a. Conservation business: sustaining Africa's future. Koedoe 44(1): 105-124.

SONNEKUS, I.P. and G J BREYTENBACH. 2001b. Reply to the comments from the Southern African Wildlife College (SAWC). Koedoe 44(1): 128.

WRENCH, J.M., H.H. MEISSNER and C.C. GRANT. 1997. Assessing diet quality of African ungulates from faecal analyses: the effect of forage quality, intake and herbivore species. Koedoe 40(1): 125-136.

\section{Augrabies Falls National Park}

BEZUIDENHOUT, H. 1996. The major vegetation communities of the Augrabies Falls National Park, Northern Cape. 1. The southern section. Koedoe 39(2): 7-24.

ZIETSMAN, P.C. and H. BEZUIDENHOUT. 1999. Flowering plant biodiversity of Augrabies Falls National Park: a comparison between Augrabies Falls National Park, Kalahari Gemsbok National Park, Vaalbos National Park and Goegap Nature Reserve. Koedoe 42(2): 95-112. 


\section{Golden Gate Highlands National Park}

WESSELS, D., D. VENTER, W. WESSELS and L. WESSELS. 1995. Experimental strain analysis of Clarens Sandstone colonised by endolithic lichens. Koedoe 38(2): 35-47.

\section{Kalahari Gemsbok National Park}

BOTHMA, J. DU P. and E.A.N. LE RICHE. 1993. Disturbance bias when tracking Kalahari leopards Panthera pardus by spoor. Koedoe 36(2): 109-112.

BOTHMA J. du P. and E.A.N. LE RICHE. 1994. Range use by an adult male caracal in the southern Kalahari. Koedoe 37(2): 105-108.

BOTHMA J. du P., N. VAN ROOYEN and E.A.N. LE RICHE. 1997. Multivariate analysis of the hunting tactics of Kalahari leopards. Koedoe 40(1): 41-56.

BOTHMA, J. DU P., S. VAN HOVEN and E.A.N. LE RICHE. 1993. GPS-corrected and GIS-based remapping of the Kalahari Gemsbok National Park and the adjacent area in Botswana. Koedoe 36(2): 105-108.

RASA, O.A.E. 1994. Behavioural adaptations to moisture as an environmental constraint in a nocturnal burrow-inhabiting Kalahari detritivore Parastizopus armaticeps Peringuey (Coleoptera: Tenebrionidae). Koedoe 37(1): 57-66.

VAN ROOYEN, N. and H. BEZUIDENHOUT. 1997. New records of flowering plants and ferns from the Kalahari Gemsbok National Park. Koedoe 40(2): 105-116.

\section{Karoo National Park}

DIPPENAAR-SCHOEMAN, ANNA S., ASTRI LEROY, MARIE DE JAGER and ANNETTE VAN DEN BERG. 1999. A check list of the spider fauna of the Karoo National Park, South Africa (Arachnida: Araneae). Koedoe 42(1): 3142.

KUNTZSCH, V. and J.A.J. NEL. 1992. Diet of bateared foxes Otocyon megalotis in the Karoo. Koedoe 35(2): 37-48.

RUBIN, FRANCINE and A.R. PALMER. 1996. The physical environment and major plant communities of the Karoo National Park, South Africa. Koedoe 39(2): 25-52.

\section{Kruger National Park}

ACKERMAN, D.J., A.J. REINECKE and H.J. ELS. 1996A. A scanning electron microscopic study of impala (Aepyceros melampus) sperm from the Kruger National Park. Koedoe 39(2): 91-104.

ACKERMAN, D.J., A.J. REINECKE and H.J. ELS. 1996B. Transmission electron microscopic study of impala (Aepyceros melampus) sperm from the Kruger National Park. Koedoe 39(2): 105-120.

ACKERMAN, D.J., A.J. REINECKE and H.J. ELS. 1997A. Transmission electron microscopic observations of flagellum abnormalities in impala (Aepyceros melampus) sperm from the Kruger National Park. Koedoe 40(1): 1-13.

ACKERMAN, D.J., A.J. REINECKE and H.J. ELS. 1997b. Transmission electron microscopic observations of acrosome and head abnormalities in impala (Aepyceros melampus) sperm from the Kruger National Park. Koedoe 40(1):15-30

AVENANT-OLDEWAGE, ANNEMARIÉ and HAZEL MARX. 2000. Manganese, nickel and strontium bioaccumulation in the tissues of the African sharptooth catfish, Clarias gariepinus from the Olifants River, Kruger National Park. Koedoe 43(2): 17-33.

BIGGS, H.C. and A.L.F. POTGIETER. 1999. Overview of the fire management policy of the Kruger National Park. Koedoe 42(1): 101-110.

BOTHA, ANNELIZE and J. HEYNS. 1992. Further records and descriptions of nematodes from rivers in the Kruger National Park (orders Enoplida, Chromadorida, Monhysterida, Mononchida and Araeolaimida). Koedoe 35(2): 11-25.

BOTHA, ANNELIZE and J. HEYNS. 1993a. New records of Tylenchida, Araeolaimida and Enoplida from the Kruger National Park, with an addendum to the check list of nematode species in the park. Koedoe 36(1): 61-65.

BOTHA, ANNELIZE and J. HEYNS. 1993b. Species of the genera Oxydirus, Dorylaimellus (Axodorylaimellus), Laimydorus and Rhabdolaimus from rivers in the Kruger National Park (Nematoda: Dorylaimida and Araeolaimida). Koedoe 36(1): 49-60.

BUERMANN, Y., H.H. DU PREEZ, G.J. STEYN, J.T. HARMSE and A. DEACON. 1995. Suspended silt concentrations in the lower Olifants River (Mpumalanga) and the impact of silt releases from the Phalaborwa Barrage on water quality and fish survival. Koedoe 38(2): 11-34.

CARRUTHERS, JANE. 1993. 'Police boys' and poachers: Africans, wildlife protection and national parks, the Transvaal 1902 to 1950 . Koedoe 36(2): 11-22.

DE KOCK, K.N. and C.T. WOLMARANS. 1998. A re-evaluation of the occurrence of freshwater molluscs in the Kruger National Park. Koedoe 41(1): 1-8.

DU PREEZ, H.H., M. VAN DER MERWE and J.H.J. VAN VUREN. 1997. Bio-accumulation of selected metals in African sharptooth catfish Clarias gariepinus from the lower Olifants River, Mpumalanga, South Africa. Koedoe 40(1): 7790.

ENGELBRECHT, W.G. and P.T. VAN DER WALT. 1993. Notes on the economic use of the Kruger National Park. Koedoe 36(2): 113-119.

ENSLIN, B.W., A.L.F. POTGIETER, H.C. BIGGS and R. BIGGS. 2000. Long term effects of fire 
frequency and season on the woody vegetation dynamics of the Sclerocarya birrea/Acacia nigrescens savanna of the Kruger National Park. Koedoe 43(1): 27-37.

FOXCROFT, L.C. and J.H. HOFFMANN. 2000. Dispersal of Dactylopius opuntiae Cockerell (Homoptera: Dactylopiidae), a biological control agent of Opuntia stricta (Haworth.) Haworth. (Cactaceae) in the Kruger National Park. Koedoe 43(2): 1-5.

GAGIANO, C.L., G.J. STEYN and H.H. DU PREEZ. 1996. Tooth replacement of tigerfish Hydrocynus vittatus from the Kruger National Park. Koedoe 39(1): 117-122.

GRANT, C.C., H.H. MEISSNER and W.A. SCHULTHEISS. 1995. The nutritive value of veld as indicated by faecal phosphorous and nitrogen and its relation to the condition and movement of prominent ruminants during the 1992-1993 drought in the Kruger National Park. Koedoe 38(1): 17-31.

GRANT, C.C. and J.L. VAN DER WALT. 2000. Towards an adaptive management approach for the conservation of rare antelope in the Kruger National Park-outcome of a workshop held in May 2000. Koedoe 43(2): 103-112.

HERITAGE, G.L. and B.P. MOON. 2000. The contemporary geomorphology of the Sabie River in the Kruger National Park. Koedoe 43(1): 39-55.

HERITAGE, G.L., B.P. MOON, G.P. JEWITT, A.R.G. LARGE and M. ROUNTREE. 2001. The February 2000 floods on the Sabie River, South Africa: an examination of their magnitude and frequency. Koedoe 44(1):37-44.

HERITAGE, G.L. and A.W. VAN NIEKERK. 1995. Drought conditions and sediment transport in the Sabie Rivier. Koedoe 38(2): 1-9.

HEYNS, J. 1994. Description of Longidoroides wiesae spec. nov. from the Kruger National Park (Nematoda: Dorylaimida). Koedoe 37(2): 97104.

HORAK, I.G., V. DE VOS and L.E.O. BRAACK. 1995. Arthropod burdens of impalas in the Skukuza region during two droughts in the Kruger National Park. 1995. Koedoe 38(1): 6571.

KEMP, A.C., K.S. BEGG, G.A. BENN and P. CHADWICK. 1997. A visual assessment of vegetation structure for the Kruger National Park. Koedoe 40(2): 117-121.

LOTTER, W.D. and J.H. HOFFMANN. 1998. An integrated management plan for the control of Opuntia stricta (cactaceae) in the Kruger National Park, South Africa. Koedoe 41(1): 63-68.

LOTTER, W.D., L. THATCHER, L. ROSSOUW and C.F. REINHARDT. 1999. The influence of baboon predation and time in water on germination and early establishment of Opuntia stricta (Australian pest pear) in the Kruger National Park. Koedoe 42(1): 43-50.
MARX, H.M. and A. AVENANT-OLDEWAGE. 1998. A further investigation into the bioaccumulation of lead and zinc in the organs and tissues of the African sharptooth catfish, Clarias gariepinus from two localities in the Olifants River, Kruger National Park. Koedoe 41(2): 27-43.

MEYER, V.W., L.E.O. BRAACK and H.C. BIGGS. 2000. Distribution and density of Cubitermes Wasmann (Isoptera: Termitidae) mounds in the northern Kruger National Park. Koedoe 43(1): 57-65.

MILLS, M.G.I. 1995. Notes on wild dog Lycaon pictus and lion Panthera leo population trends during a drought in the Kruger National Park. Koedoe 38(1): 95-99.

MOON, B.P. and G.L. HERITAGE. 2001. The contemporary geomorphology of the Letaba River in the Kruger National Park. Koedoe 44(1): 45-55.

PIENAAR, D. J., J. DU P. BOTHMA and G. K. THERON. 1993. Landscape preference of the white rhinoceros in the central and northern Kruger National Park. Koedoe 36(1): 79-86.

PRETORIUS, QUARTA, B.P. PRETORIUS and C.S. DANNHAUSER. 1996. The reproductive behaviour of the suni Neotragus moschatus zuluensis in captivity. Koedoe 39(1): 123-126.

SCHOLES, R.J., N. GUREJA, M. GIANNECCHINNI, D. DOVIE, B. WILSON, N. DAVIDSON, K. PIGGOTT, C. MCLOUGHLIN, K. VAN DER VELDE, A FREEMAN, S. BRADLEY, R. SMART and S. NDALA. 2001. The environment and vegetation of the flux measurement site near Skukuza, Kruger National Park. Koedoe 44(1): 73-83.

SEYMORE, T., H.H. DU PREEZ, J.H.J. VAN VUREN, A. DEACON and G. STRYDOM. 1994. Variations in selected water quality variables and metal concentrations in the sediment of the lower Olifants and Selati rivers, South Africa. Koedoe 37(2): 1-18.

SHACKLETON, C.M. and R.J. SCHOLES. 2000. Impact of fire frequency on woody community structure and soil nutrients in the Kruger National Park. Koedoe 43(1): 75-81.

SOLOMON, M., N. ZAMBATIS, H.C. BIGGS and N. MARÉ. 1999. Comparison of classifications commonly used as templates for management, scientific and GIS work in the Kruger National Park. Koedoe 42(2): 131-142.

SPICKETT, A.M., I.G. HORAK, HELOISE HEYNE and L.E.O. BRAACK. 1995. The effect of severe drought on the abundance of ticks on vegetation and on scrub hares in the Kruger National Park. 1995. Koedoe 38(1): 59-64.

SWANEPOEL, D. G. J. 1996. Identification of the Nile crocodile Crocodylus niloticus by the use of natural tail marks. Koedoe 39(1): 113-116.

SWANEPOEL, D.G.J., N.S. FERGUSON and M.R. PERRIN. 2000. Nesting ecology of Nile crocodiles (Crocodylus niloticus) in the Olifants River, Kruger National Park. Koedoe 43(2): 35-46. 
THRASH, I., G.K. THERON and J. DU P. BOTHMA. 1993. Herbivore dung deposit counts around drinking troughs in the Kruger National Park. Koedoe 36(1): 87-94.

TROLLOPE, W.S.W. 1993. Fire regime of the Kruger National Park for the period 1980 - 1992. Koedoe 36(2): 45-52.

TROLLOPE, W.S.W., L.A. TROLLOPE, H.C. BIGGS, D. PIENAAR and A.L.F. POTGIETER. 1998. Long term changes in the woody vegetation of the Kruger National Park, with special ref erence to the effects of elephants and fire. Koedoe 41(2): 103-112.

VAN DER MERWE, MARINDA, J.H.J. VAN VUREN and H.H. DU PREEZ. 1993. Lethal copper concentration levels for Clarias gariepinus (Burchell, 1822) a preliminary study. Koedoe 36(2): 77-86.

VAN DER WAAL, B.C.W. 1998. Survival strategies of sharptooth catfish Clarias gariepinus in desiccating pans in the northern Kruger National Park. Koedoe 41(2): 131-138.

VAN VOLLENHOVEN, ANTON C., ANTON J. PELSER \& JAN W. VAN DEN BOS. 1998. A historical-archaeological investigation of an Anglo-Boer War British outpost in the Kruger National Park. Koedoe 41(2): 113-120.

VAN WILGEN, B.W., H.C. BIGGS and A.L.F. POTGIETER. 1998. Fire management and research in the Kruger National Park, with suggestions on the detection of thresholds of potential concern. Koedoe 41(1): 69-87.

VILJOEN, A.J. 1995. The influence of the 1991/92 drought on the woody vegetation of the Kruger National Park. Koedoe 38(2): 85-97.

VILJOEN, P.C. 1995. Changes in number and distribution of hippopotamus (Hippopotamus amphibius) in the Sabie River, Kruger National Park, during the 1992 drought. Koedoe 38(2): 115-121.

VILJOEN, P.C. and P.F. RETIEF. 1994. The use of the Global Positioning System for real-time data collecting during ecological aerial surveys in the Kruger National Park, South Africa. Koedoe 37(1): 149-157.

WEPENER, V, N. EULER, J.H.J. VAN VUREN, H.H. DU PREEZand ASTRI KÖHLER. 1992. The development of an aquatic toxicity index as a tool in the operational management of water quality in the Olifants River (Kruger National Park). Koedoe 35(2): 1-9.

WEPENER, V., J.H.J. VAN VUREN and H.H. DU PREEZ. 1999. The implementation of an aquatic toxicity index as a water quality monitoring tool in the Olifants River (Kruger National Park). Koedoe 42(1): 85-96.

WRENCH, J.M., H.H. MEISSNER, C.C. GRANT and N.H. CASEY. 1996. Environmental factors that affect the concentration of $\mathrm{P}$ and $\mathrm{N}$ in faecal samples collected for the determination of nutritional status. Koedoe 39(2): 1-6.
WRENCH, J.M., H.H. MEISSNER and C.C. GRANT. 1997. Assessing diet quality of African ungulates from faecal analyses: the effect of forage quality, intake and herbivore species. Koedoe 40(1): 125-136.

ZAMBATIS, N and H.C. BIGGS. 1995. Rainfall and temperatures during the 1991/92 drought in the Kruger National Park. Koedoe 38(1): 1-16.

\section{Mountain Zebra National Park}

BROWN, L.R. and H. BEZUIDENHOUT. 2000. The phytosociology of the De Rust section of the Mountain Zebra National Park, Eastern Cape. Koedoe 43(1): 1-18.

DE KLERK, J., L.R. BROWN, H. BEZUIDENHOUT and G. CASTLEY. 2001. The estimation of herbage yields under fire and grazing treatments in the Mountain Zebra National Park. Koedoe 44(1): 9-15.

NOVELLIE, P.A. 1994. Monitoring the condition of mountain zebra habitat in the Mountain Zebra National Park. Koedoe 37(1): 35-39.

WESSELS, DIRK and LUDGER KAPPEN. 1993. Photosynthetic performance of rock-colonising lichens in the Mountain Zebra National Park, South Africa. Koedoe 36(1): 27-48.

WINKLER, A. and N. OWEN-SMITH. 1995. Habitat utilisation by Cape mountain zebras in the Mountain Zebra National Park. Koedoe 38(1): 83-93.

\section{Richtersveld National Park}

WEBLEY, LITA, FIONA ARCHER and J. BRINK. 1993. Die Toon: a Late Holocene site in the Richtersveld National Park, northern Cape. Koedoe 36(2): 1-9.

\section{Tsitsikamma National Park}

HANEKOM, N., J.B. MANN-LANG, B.Q. MANN and T.V.Z. CARINUS. 1997. Shore-angling catches in the Tsitsikamma National Park, 19891995. Koedoe 40(2): 37-56.

MANN, B.Q. and C.D. BUXTON. 1992. Diets of Diplodus sargus capensis and D. cervinus hottentotus (Pisces: Sparidae) on the Tsitsikamma coast, South Africa. Koedoe 35(2): 27-36.

VAN DEN BERG, ESTHER. 1996. A first list of plant-parasitic nematodes from the Tsitsikamma National Park, with descriptions of two new species of the subfamily Criconematinae. Koedoe 39(1): 43-54.

WOOD, A.D., S.L. BROUWER, P.D. COWLEY and T.D. HARRISON. 2000. An updated check list of the ichthyofaunal species assemblage of 
the Tsitsikamma National Park, South Africa. Koedoe 43(1): 83-95.

\section{Vaalbos National Park}

BANCROFT, C.M., H. BEZUIDENHOUT and J.G. NEL. 1998. Use of veld condition assessment to set objectives and targets for an ISO 14001 environmental management system for Vaalbos National Park. Koedoe 41(2): 1-12.

BEZUIDENHOUT, H. 1994. An ecological study of the major vegetation communities of the Vaalbos National Park, Northern Cape. 1. The ThanDroogeveld section. Koedoe 37(2): 19-44.

BEZUIDENHOUT, H. 1995. An ecological study of the major vegetation communities of the Vaalbos National Park, Norhtern Cape. 2. The GraspanHolpan section. Koedoe 38(2): 65-83.

RUSSELL, I.A. 1997. Spatial variation in the structure of fish assemblages in the Vaalbos National Park. Koedoe 40(1): 113-123.

ZIETSMAN, P.C. and H. BEZUIDENHOUT. 1999. Flowering plant biodiversity of Augrabies Falls National Park: a comparison between Augrabies Falls National Park, Kalahari Gemsbok National Park, Vaalbos National Park and Goegap Nature Reserve. Koedoe 42(2): 95-112.

\section{West Coast National Park}

CORDES, I.G. and P. LE F.N. MOUTON. 1996. The conservation status of the Saldanha-Langebaan lizard fauna. Koedoe 39(1): 71-84.

\section{Wilnerness National Park}

RUSSELL, I.A. 1999a. Changes in the water quality of the Wilderness and Swartvlei lake systems, South Africa. Koedoe 42(1): 57-72.

RUSSELL, I.A. 1999b. Freshwater fish of the Wilderness National Park. Koedoe 42(1): 73-78.

VAN DEN BERG, ESTHER. 1993. A first list of plant-parasitic nematodes from the Wilderness National Park, with a description of Ogma sekgwaum spec. nov. Koedoe 36(2): 61-76.

\section{Nature Reserves and 'other' national parks}

ANDERSON, M.D. and J.H. KOEN. 1993. Body measurements of mountain reedbuck Redunca fulvorufula fulvorufula from Rolfontein Nature Reserve, South Africa. Koedoe 36(1): 99-101.

AVENANT, N.L. 1997. Mammals recorded in the QwaQwa National Park (1994-1995). Koedoe 40(1): 31-40.

AVENANT-OLDEWAGE, ANNEMARIÉ. 1994. A new species of Argulus from Lake Kosi Bay,
South Africa and distribution records of the genus. Koedoe 37(2): 89-96.

BHIMA, R. and J. DU P. BOTHMA. 1997. Age structure of elephants in Liwonde National Park, Malawi. Koedoe 40(2): 1-8.

BHIMA, R. and C.O. DUDLEY. 1997. The influence of the Shire River on Liwonde National Park, Malawi, with special reference to elephant movements. Koedoe 40(2): 9-18.

BREDENKAMP, G.J., H. BEZUIDENHOUT, $\mathrm{H}$. JOUBERT and C. NAUDE. 1994. The vegetation of the Boskop Dam Nature Reserve, Potchefstroom. Koedoe 37(1): 19-33.

BREDENKAMP, G.J. and M.S. DEUTSCHLÄNDER. 1994. The Themedo triandrae - Setarietum incrassatae, a new association from gabbro in the Manyeleti Game Reserve, Gazankulu, South Africa. Koedoe 37(2): 45-58.

BREDENKAMP, G.J. and M.S. DEUTSCHLÄNDER. 1995. New azonal syntaxa from the hills and river banks of the Manyeleti Game Reserve, Northern Transvaal Province, South Africa. Koedoe 38(1): 41-58.

BREEBAART, L. and M. DEUTSCHLÄNDER. 1997. The vegetation types and management units of Goedverwacht farm in the mixed bushveld of the Northern Province, South Africa. Koedoe 40(2): 19-35.

BROWN, L.R. and G.J. BREDENKAMP. 1994. The phytosociology of the southern section of Borakalalo Nature Reserve, South Africa. Koedoe 37(2): 59-72.

BROWN, L.R., G.J. BREDENKAMP and N. VAN ROOYEN. 1995. The phytosociology of the western section of Borakalalo Nature Reserve. Koedoe 38(2): 49-64.

BROWN, L.R., G.J. BREDENKAMP and N. VAN ROOYEN. 1996. The phytosociology of the northern section of the Borakalalo Nature Reserve. Koedoe 39(1): 9-24.

CAULDWELL, A.E., U.ZIEGER, M.G. BINGHAM and G.J. BREDENKAMP. 1998. Classification of the natural vegetation of Mtendere Game Ranch in the Chibombo District of the Central Province, Zambia. Koedoe 41(2): 13-26.

CILLIERS, S.S., E. VAN WYK and G.J BREDENKAMP. 1999. Urban nature conservation: vegetation of natural areas in the Potchefstroom municipal area, North West Province, South Africa. Koedoe 42(1): 1-30.

DE SWARDT, D.H. and D.J. VAN NIEKERK. 1996. An annotated check list of the birds of Qwaqwa National Park. Koedoe 39(1): 89-106.

DEUTSCHLÄNDER, M.S. and G.J. BREDENKAMP. 1999. Importance of vegetation analysis in the conservation management of the endangered butterfly Aloeides dentatis dentatis (Swierstra) (Lepidoptera, Lycaenidae). Koedoe 42(2): $1-12$

DUDLEY, C.O. 1997. The candelabra tree (Euphorbia ingens): a source of water for black rhinocer- 
os in Liwonde National Park, Malawi. Koedoe 40(1): 57-62.

DU PLESSIS, W.P. 1997. Refinements to the burning strategy in the Etosha National Park, Namibia. Koedoe 40(1):63-76.

DU PLESSIS, W.P., G.J. BREDENKAMP and W.S.W. TROLLOPE. 1998a. Response of herbaceous species to a degradation gradient in the western region of Etosha National Park, Namibia. Koedoe 41(1): 9-18.

DU PLESSIS, W.P., G.J. BREDENKAMP and W.S.W. TROLLOPE. 1998b. Development of a technique for assessing veld condition in Etosha National Park, Namibia, using key herbaceous species. Koedoe 41(1): 19-30.

ELS, L.M. and G.I.H. KERLEY. 1996. Biotic and abiotic correlates of small mammal community structure in the Groendal Wilderness Area, Eastern Cape, South Africa. Koedoe 39(2): 121.

HISCOCKS, Kay. 1999. The impact of an increasing elephant population on the woody vegetation in southern Sabi Sand Wildtuin, South Africa. Koedoe 42(2): 47-55.

KYLE, R. 2000. Some notes on the occurrence and conservation status of Manis temminckii, the pangolin, in Maputaland, Kwazulu/Natal. Koedoe 43(1): 97-100.

MATTHEWS, W.S. G.J. BREDENKAMP and N. VAN ROOYEN. 1994. The phytosociology and syntaxonomy of relatively low-altitude areas in the North-eastern Mountain Sourveld, in the eastern Transvaal escarpment region. Koedoe 37(2): 73-88.

MWIMA, H.K. 2001. A brief history of Kafue National Park, Zambia. Koedoe 44(1): 57-72.
PENZHORN, B.L. and N.J. VAN DER MERWE. 1993. Testis size and spermatogenesis of tsessebes from Nylsvley Nature Reserve, Transval. Koedoe 36(1): 95-98.

RÖSCH, HELGA. 2001. The identification and description of the management units of the Goegap Nature Reserve. Koedoe 44(1): 17-30.

SLOTOW, R. and G. VAN DYK. 2001. Role of delinquent young "orphan" male elephants in high mortality of white rhinoceros in Pilanesberg National Park, South Africa. Koedoe 44(1): 85-94.

SMIT, C.M., G.J. BREDENKAMP, N. VAN ROOYEN, A.E. VAN WYK and J.M. COMBRINCK. 1997. Vegetation of the Witbank Nature Reserve and its importance for conservation of threatened Rocky Highveld Grassland. Koedoe 40(2): 85-104.

VAN DIJK, D.E. 1996. Anuran fauna of the Lesotho Highlands in the Khatse Dam catchment area and Jorodane River region. Koedoe 39(2): 77-90.

VISSER, N., W. VAN HOVEN and G.K. THERON. 1996. The vegetation and identification of management units of the Honnet Nature Reserve, Northern Province, South Africa. Koedoe 39(1): 25-42.

ZIETSMAN, P.C. and H. BEZUIDENHOUT. 1999. Flowering plant biodiversity of Augrabies Falls National Park: a comparison between Augrabies Falls National Park, Kalahari Gemsbok National Park, Vaalbos National Park and Goegap Nature Reserve. Koedoe 42(2): 95-112. 